\title{
Multi-model impacts of climate change on pollution transport from global emission source regions
}

\author{
Ruth M. Doherty ${ }^{1}$, Clara Orbe ${ }^{2}$, Guang Zeng ${ }^{3}$, David A. Plummer ${ }^{4}$, Michael J. Prather ${ }^{5}$, Oliver Wild ${ }^{6}$, Meiyun Lin ${ }^{7,8}$, \\ Drew T. Shindell ${ }^{\text {}}$, and Ian A. Mackenzie ${ }^{1}$ \\ ${ }^{1}$ School of GeoSciences, University of Edinburgh, Edinburgh, EH9 3FF, UK \\ ${ }^{2}$ Goddard Earth Sciences Technology and Research (GESTAR), Johns Hopkins University, Baltimore, MD 21218, USA \\ ${ }^{3}$ National Institute of Water and Atmospheric Research, Wellington 6021, New Zealand \\ ${ }^{4}$ Canadian Centre for Climate Modelling and Analysis, Environment and Climate Change Canada, Montréal, QC, Canada \\ ${ }^{5}$ Department of Earth System Science, University of California, Irvine, Irvine, CA 92697-3100, USA \\ ${ }^{6}$ Lancaster Environment Centre, Lancaster University, Lancaster, LA1 4YQ, UK \\ ${ }^{7}$ Program in Atmospheric and Oceanic Sciences at Princeton University, Princeton, NJ 08540, USA \\ ${ }^{8}$ NOAA Geophysical Fluid Dynamics Laboratory, Princeton, NJ 08540, USA \\ ${ }^{9}$ Nicholas School of the Environment, Duke University, Durham, NC 27708, USA
}

Correspondence to: Ruth M. Doherty (ruth.doherty@ed.ac.uk)

Received: 19 May 2017 - Discussion started: 26 June 2017

Revised: 8 October 2017 - Accepted: 9 October 2017 - Published: 30 November 2017

\begin{abstract}
The impacts of climate change on tropospheric transport, diagnosed from a carbon monoxide (CO)-like tracer species emitted from global $\mathrm{CO}$ sources, are evaluated from an ensemble of four chemistry-climate models (CCMs) contributing to the Atmospheric Chemistry and Climate Model Intercomparison Project (ACCMIP). Model time-slice simulations for present-day and end-of-the-21stcentury conditions were performed under the Representative Concentrations Pathway (RCP) climate scenario RCP 8.5. All simulations reveal a strong seasonality in transport, especially over the tropics. The highest $\mathrm{CO}$-tracer mixing ratios aloft occur during boreal winter when strong vertical transport is co-located with biomass burning emission source regions. A consistent and robust decrease in future CO-tracer mixing ratios throughout most of the troposphere, especially in the tropics, and an increase around the tropopause is found across the four CCMs in both winter and summer. Decreases in CO-tracer mixing ratios in the tropical troposphere are associated with reduced convective mass fluxes in this region, which in turn may reflect a weaker Hadley cell circulation in the future climate. Increases in CO-tracer mixing ratios near the tropopause are largely attributable to a rise in tropopause height enabling lofting to higher altitudes, although a poleward shift in the mid-latitude jets may also play a minor
\end{abstract}

role in the extratropical upper troposphere. An increase in CO-tracer mixing ratios also occurs near the Equator, centred over equatorial and Central Africa, extending from the surface to the mid-troposphere. This is most likely related to localised decreases in convection in the vicinity of the Intertropical Convergence Zone (ITCZ), resulting in larger CO-tracer mixing ratios over biomass burning regions and smaller mixing ratios downwind.

\section{Introduction}

The transport of pollutants from the atmospheric boundary layer is governed by meteorological processes including deep convection, Hadley-cell-driven overturning in the tropics, and mid-latitude cyclones, as well as slow low-altitude airflow, small-scale turbulent mixing, and other motions (e.g. Cooper et al., 2011; TF-HTAP, 2010). Climate change may affect the large-scale circulation of the atmosphere through the above processes and hence impact the intercontinental transport of pollutants. In addition to influencing meteorological transport processes, changes in climate will also modify the atmospheric chemical environment and pollutant lifetimes. To understand how these changes will influence future 
pollutant distributions, it is therefore important to disentangle the relative impacts of changes in transport and chemistry as well as future emission changes. The focus of this study is to quantify climate change impacts on atmospheric transport.

In the tropics, the Hadley circulation determines the location of the Intertropical Convergence Zone (ITCZ) (e.g. Kang et al., 2013). Deep convection and mean upwelling associated with the Hadley circulation control transport processes influencing pollutant distributions. For example, satellite measurements from the MOPITT (Measurements of Pollution in the Troposphere) instrument reveal that deep convection during the Asian summer monsoon carries pollutants emitted at the surface aloft into the upper troposphere (Kar et al., 2004). Deep convective transport of biomass burning emissions into the middle and upper troposphere was observed over Brazil during the TRACE A atmospheric chemistry field campaign experiment (Pickering et al., 1996).

Over the mid-latitudes, ascent of pollution from the surface to the mid- to upper troposphere occurs along warm conveyor belt airstreams embedded within synoptic-scale midlatitude cyclones (Cooper et al., 2004; Brown-Steiner and Hess, 2011; Lin et al., 2012). Descent from the lower stratosphere and upper troposphere to the mid-troposphere can occur in the dry intrusion airstreams of cyclones (e.g. Langford et al., 2015; Knowland et al., 2015). This is also the main mechanism for stratosphere-troposphere exchange of ozone that occurs in the mid-latitudes and which may extend to the surface in regions prone to deep stratospheric ozone intrusions (Lin et al., 2015). Deep convection is also important for lofting surface pollution in mid-latitude regions in summer when the landmass is warm.

Changes in climate may influence many of these tropical and mid-latitude transport processes, but the impact of these future changes on chemical composition remains unclear. In the tropics and subtropics a number of studies have shown a poleward expansion and weakening of the Hadley cell circulation in response to future increases in greenhouse gases (GHGs), which is most robust in boreal winter (Vecchi and Soden, 2007; Lu et al., 2007; Ma et al., 2012; Levine and Schneider, 2011; Williamson et al., 2013; Seo et al., 2014; Kang et al., 2013). While these studies posit that the weakening of the Hadley cell is related to a weakening of the meridional temperature gradient between the tropics and subtropics, other studies have invoked thermodynamic constraints to suggest that convective mass fluxes throughout the tropics may decrease in response to increasing greenhouse gases (Held and Soden, 2006).

As temperatures increase in the troposphere but decrease in the stratosphere in response to enhanced $\mathrm{CO}_{2}$ concentrations, there is a decrease in static stability close to the tropopause that leads to an increase in its height (Manabe and Wetherald, 1975; Santer et al., 2003; Lorenz and De Weaver, 2007; Kang et al., 2013; Vallis et al., 2015). A higher tropopause may also be associated with a poleward expan- sion or widening of the Hadley cell (Lu et al., 2007), but the mechanisms underlying this change remain unclear.

Over the mid-latitudes, there is a general consensus that the storm tracks will shift poleward in response to future increases in greenhouse gases, at least in the zonal mean (Yin et al., 2005; Bengtssen et al., 2006; Barnes et al., 2013; Christensen et al., 2013; Shaw et al., 2016). This poleward shift in the mid-latitude storm tracks has been dynamically linked to the weakening of the Hadley circulation in the tropics (Vallis et al., 2015; Shaw et al., 2016) and to the rise in tropopause height (Lorenz and De Weaver, 2007). However, the zonally asymmetric and seasonally varying response of mid-latitude storm tracks to forced climate change is much less robust (Simpson et al., 2014; Shaw et al., 2016), partly due to interannual variability (Deser et al., 2012; Shepherd, 2014).

In terms of ozone pollution transport, this shift in the midlatitude storm track position has been related to reduced midlatitude cyclone frequency leading to increased summertime surface $\mathrm{O}_{3}$ pollution episodes over the eastern USA and $\mathrm{Eu}-$ rope (Mickley et al., 2004; Forkel and Knoche, 2006; Murazaki and Hess, 2006; Leibensperger et al., 2008; Wu et al., 2008), although other studies do not report such changes in frequency (Racherla and Adams, 2008; Lang and Waugh, 2011). The shift in mid-latitude storm tracks has also been related to changes in regional climate phenomena in particular the North Atlantic Oscillation (Ulbrich et al., 2009; Christensen et al., 2013), blocking anticyclone frequency (Masato et al., 2013), and the Pacific Decadal Oscillation (Lin et al., 2014; Allen et al., 2014). Ozone transport from the lower stratosphere to the troposphere will also be influenced by future changes in stratosphere-troposphere exchange, which is expected to increase under greenhouse gas warming owing to a strengthening of the Brewer-Dobson circulation in the stratosphere, leading to higher ozone mixing ratios in the mid- to upper troposphere (Butchart and Scaife, 2001; Neu et al., 2014). Higher mixing ratios of idealised tracers of stratospheric origin in the tropical and subtropical troposphere have also been found due to enhanced stratosphere-troposphere exchange in a future warmer climate (Orbe et al., 2013a; Abalos et al., 2017).

Few studies have explicitly isolated the effects of climate change on pollutant transport from its effects on chemical processes (e.g. through enhanced chemical reaction rates or changes in natural climate-sensitive emissions). Idealised tracers from surface sources used by Holzer and Boer (2001) showed increases in interhemispheric exchange times, mixing times, and mean transit times between 2000 and 2100. This study also found a $25 \%$ lower tropospheric average tracer mixing ratio as well as a reduced cross-tropopause tracer gradient, which was attributed to a slightly higher tropopause. More recently, Orbe et al. (2015) used idealised tracers of air-mass origin, as described in Orbe et al. (2013b), to track how future increases in greenhouse gases modified transport patterns extending from the northern mid-latitude boundary layer into the Arctic. Using idealised tracers they 
diagnosed enhanced poleward transport of the mid-latitude air arising from the poleward migration of the mid-latitude storm tracks, as outlined above.

Using a carbon monoxide (CO)-like tracer, which has present-day fossil fuel emissions as its source and loss by reaction with present-day $\mathrm{OH}$, Mickley et al. (2004) related $5-10 \%$ enhancements at the high percentile values of summer CO-tracer distributions in the United States to reduced cyclone passage across southern Canada under a future 2050 climate compared to present day. Several other studies have used idealised $\mathrm{CO}$ tracers emitted from continental sources to investigate climate variability and change impacts on pollutant transport (Shindell et al., 2008; Doherty et al., 2013; Lin et al., 2014; Monks et. al. 2015). Using a regional COlike tracer with surface emissions from Asia held constant, Lin et al. (2014) examined the mean influence of Eurasian pollution over the subtropical North Pacific, influenced by the position of the subtropical jet and its decadal variability. Under the SRES A2 climate forcing scenario for the 2090s compared to the 2000s, distinct dipole patterns in the changes in surface $\mathrm{CO}$-tracer mixing ratios were interpreted as a response to future shifts in regional circulations within four continental regions and their outflow locations (Doherty et al., 2013).

A detailed analysis by Fang et al. (2011) used a global CO-like tracer with a first-order 25-day lifetime and global anthropogenic $\mathrm{CO}$ emissions to investigate changes in transport under the SRES A1B scenario between 1981-2000 and 2081-2100 using the GFDL AM3 chemistry-climate model (CCM). They found that CO-tracer mixing ratios increased at the surface and decreased in the tropical free troposphere due to reduced convective mass fluxes and that reduced CO-tracer mixing ratios in the Southern Hemisphere were most likely a response to a weaker Hadley circulation and reduced interhemispheric exchange (Fang et al., 2011). A large increase in CO-tracer mixing ratios near the tropopause was suggested to arise from the upward migration of the tropopause (Fang et al., 2011). This study focussed on annual-mean distributions. Similarly, the trends in mixing ratios of a 90-day $e$ folding (e90) tracer between 1955 and 2099 have been related to trends in tropopause height (Abalos et al., 2017).

The aim of this paper is to explore the robustness of the changes in transport found in the single-model study described above across an ensemble of CCMs participating in the recent Atmospheric Chemistry and Climate Model Intercomparison Project (ACCMIP) using a globally emitted CO tracer (Lamarque et al., 2013) and to quantify for the first time seasonal transport changes in response to climate change and their dynamical attribution. Section 2 describes the models used while Sect. 3 discusses future changes in CO-tracer mixing ratios (with emissions held constant). Section 4 outlines the transport processes and circulation changes that most likely drive $\mathrm{CO}$-tracer redistribution under climate change. Discussion and conclusions are presented in Sect. 5.

\section{Data sets and methods}

In the ACCMIP model intercomparison, four global CCMs included a CO-like tracer emitted from global sources: UM-CAM, GISS-E2-R, CMAM, and STOC-HadAM3. A description of these models, including their chemistry, transport, and configuration, can be found in Lamarque et al. (2013) and Young et al. (2013). The horizontal resolution of the models varied between $1.875^{\circ}$ by $2.5^{\circ}$ and $5^{\circ}$ by $5^{\circ}$. Two of the models, UM-CAM and STOC-HadAM3, have the same driving global climate model (GCM); however, their advection schemes differ substantially since STOCHadAM3 is the only model to use a Lagrangian approach to simulate transport processes. Deep convection schemes used by the models are based on two main parameterisations: Gregory and Rowntree (1990) for GISS-E2-R, UM-CAM, and STOC-HadAM3; and Zhang and McFarlane (1995) for CMAM. In addition, STOC-HadAM3 uses Collins et al. (2002) to derive using convective mass fluxes the probability of a parcel being subject to convective transport. Although these two parameterisations are based on a mass flux approach, there can be a wide spread in simulated convective mass fluxes within a single parameterisation (Scinocca and McFarlane, 2004; Lamarque et al., 2013). In addition, how the transport of the $\mathrm{CO}$ tracer is implemented will influence the impacts of the convection schemes. The simulations were performed using decadal-average monthly sea surface temperature and sea ice concentration distributions for two 10-year periods: present day ("acchist" simulations) as represented by a period centred on the year 2000 (1996-2005) and a future projection under the latest IPCC Representative Concentration Pathway (RCP) RCP 8.5 scenario for 2090-2099. Note that each modelling group derived their own set of sea surface temperature and sea ice fields, typically from a closely related coupled-ocean GCM. Under RCP 8.5 the increase in global mean surface temperature between 2081 and 2100 , relative to $1986-2005$, is projected to be $2.6-4.8^{\circ} \mathrm{C}$ averaged across all ( $\left.\sim 39\right)$ participating GCMs (Collins et al., 2013). For the four models used here the global mean surface temperature change between $1996-2005$ and $2090-2099$ is $3.1-4.6^{\circ} \mathrm{C}$.

The CO-like tracer was implemented as a chemically inert species with monthly-varying emissions representing all global anthropogenic and biomass burning $\mathrm{CO}$ sources with a first-order decay lifetime of 50 days (Shindell et al., 2008; Fang et al., 2011; Doherty et al., 2013). This idealised tracer is relatively long lived such that it can undergo interhemispheric transport and be used to diagnose how changes in transport from source regions affect the distributions of trace gas species with similar lifetimes (such as $\mathrm{CO}$ and $\mathrm{O}_{3}$ ). Monthly CO-tracer fields were generated for two 10-year periods (1996-2005 and 2090-2099), and the four models used the same emissions data for 2001 for both time periods. Thus, for each CCM the differences in CO-tracer mixing ratio distributions between these two periods are due solely to 
(a)

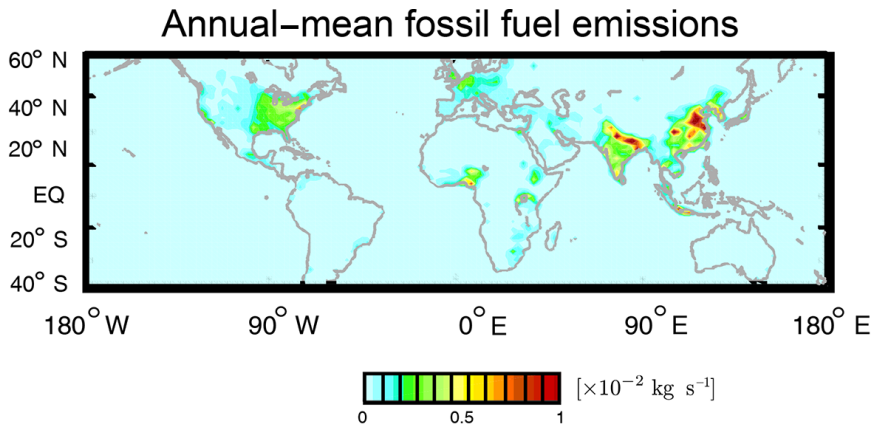

(b)

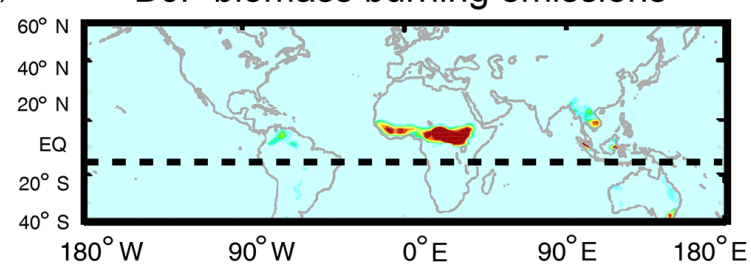

(c)

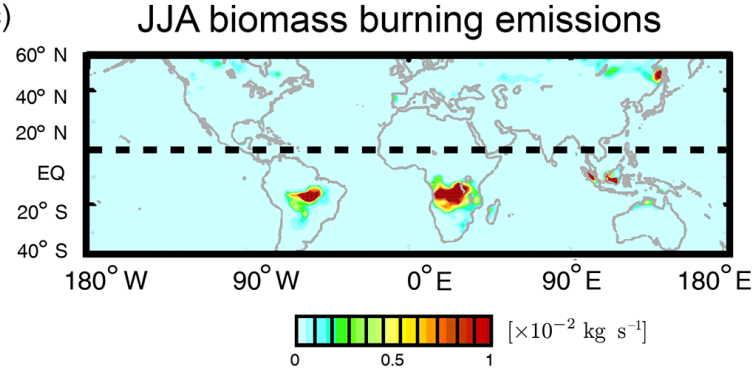

MAM biomass burning emissions

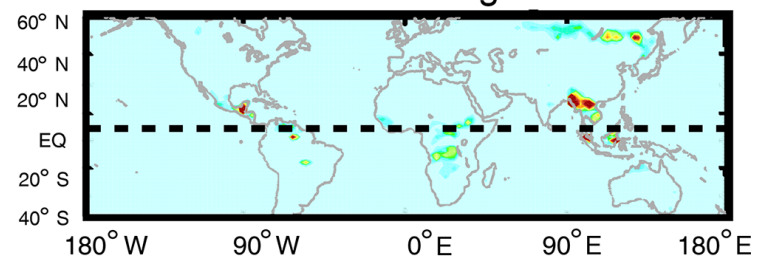

SON biomass burning emissions

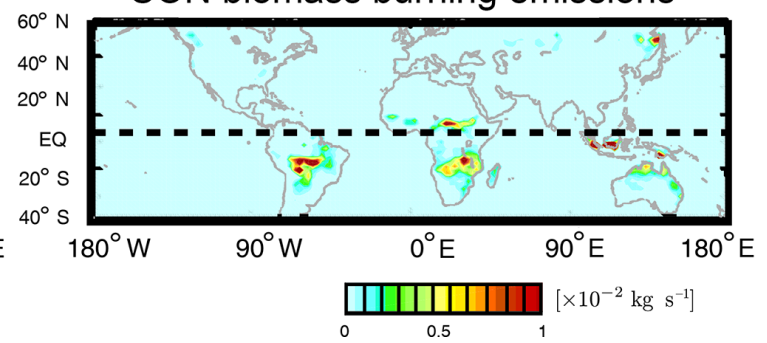

Figure 1. Annual-mean anthropogenic $\mathrm{CO}$ emissions $\left(\mathrm{kg} \mathrm{s}^{-1}\right)$ from fossil fuels (a) and seasonal-mean biomass burning CO emissions for the different seasons $\left(\mathrm{kg} \mathrm{s}^{-1}\right)$ (b and $\left.\mathbf{c}\right)$. The dashed line shows the approximate position of the Intertropical Convergence Zone (ITCZ) in the different seasons.

how climate change affects transport from global emission regions. To establish whether the CO-tracer distributions in the present-day (1996-2005) and future (2090-2099) periods are significantly different, a Student's $t$ test was performed using the 10 years of annual data for each period for each model grid cell; a $p$ value $<0.05$ was used to determine statistical significance.

The Task Force on Hemispheric Transport of Air Pollution (TF-HTAP, 2010) CO-tracer emissions data set was used in ACCMIP, which consists of annual-mean anthropogenic emissions for the year 2001 from the RETRO project (Schultz and Rast, 2007) and monthly average biomass burning emissions (injected into the models at, or near, the surface) from GFED version 2 (van der Werf et al., 2006; http: //www.globalfiredata.org/). The major source regions for anthropogenic $\mathrm{CO}$ emissions are in the northern mid-latitudes with peak levels in East and South Asia (Fig. 1). Unlike the anthropogenic emissions, the biomass burning emissions feature a strong seasonality, with high values over equatorial Africa during December-January-February (DJF), peak val- ues southward of the Equator in South America and Central Africa in June-July-August (JJA), and a stronger peak value in Southeast Asia during JJA (Fig. 1). The location of these emission peaks in relation to the position of the ITCZ can be clearly seen in Fig. 1. Biomass emissions during March-April-May (MAM) and September-OctoberNovember (SON) are significantly weaker (Fig. 1).

Temperature data from the four CCMs were used to calculate the thermal tropopause following the World Meteorological Organization (WMO) lapse rate definition as implemented by Reichler et al. (2003) for gridded reanalysis data. The tropopause is defined separately as an average for the 2000s and the 2090s as the lowest model level at which the lapse rate decreases to $2^{\circ} \mathrm{C} \mathrm{km}^{-1}$, provided that the average lapse rate between this level and higher levels does not exceed this. Studies have shown the lapse rate or thermal tropopause approximately coincides with the e90 tracer tropopause which is used to distinguish stratospheric and tropospheric air (Prather et al., 2011; Abalos et al., 2017). Convective mass flux and zonal $(u)$ wind data (available for three 
(a) UM-CAM

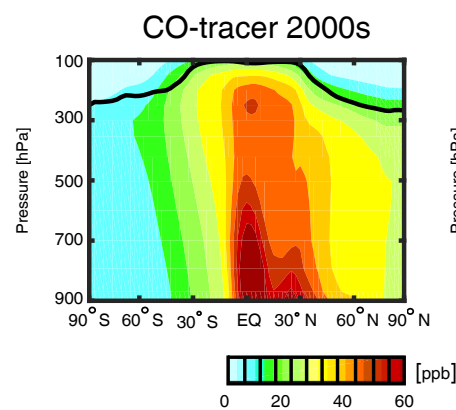

$\triangle$ CO-tracer 2090s-2000s

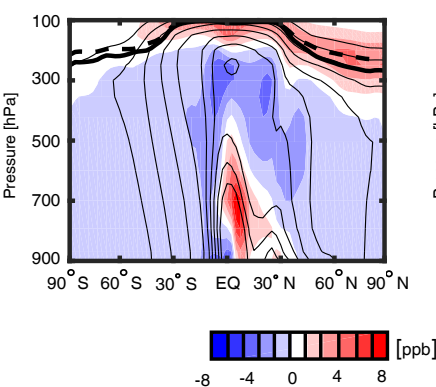

(b) STOC-HadAM3

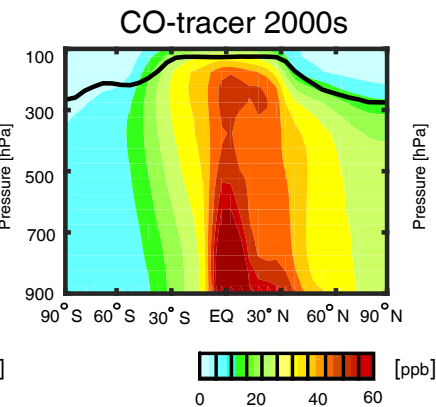

(c) CMAM

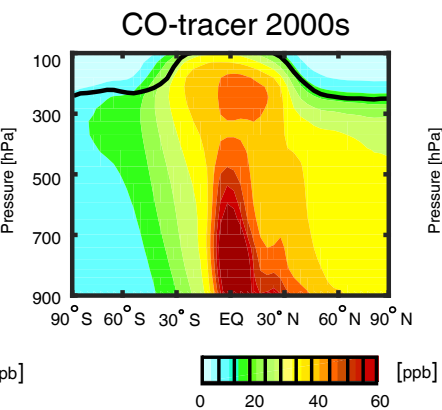

(d) GISS-E2-R
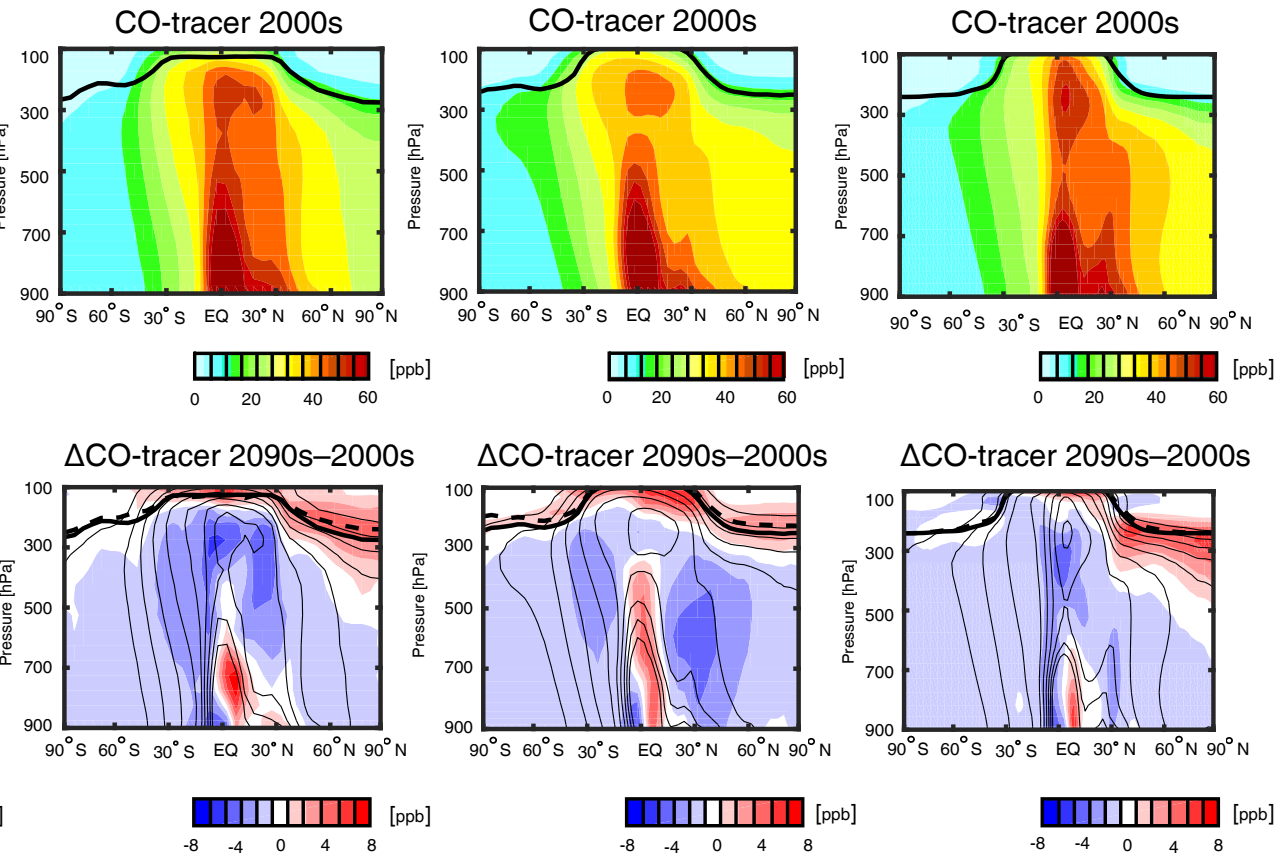

$\Delta$ CO-tracer 2090s-2000s
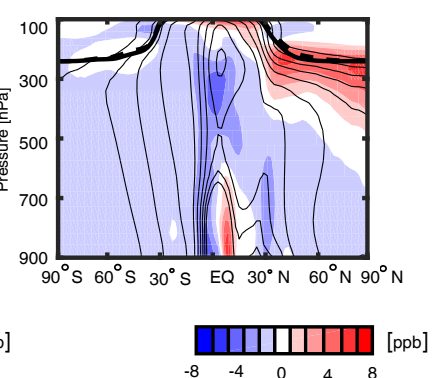

Figure 2. Top panels: present-day (1995-2006) boreal winter (DJF) 10-year climatological mean zonal-mean CO-tracer distribution for (a) UM-CAM, (b) STOC-HadAM3, (c) CMAM, and (d) GISS-E2-R CCMs. The thick black solid line represents the present-day (DJF) zonally averaged thermal tropopause. Bottom panels: differences between 2090-2099 (RCP 8.5) and 1995-2006 (present day) DJF climatological mean zonal-mean CO distributions. Thin black contours denote the present-day DJF climatology. The thick solid and dashed lines represent the DJF zonally averaged thermal tropopause for present-day and the 2090s (RCP 8.5) climatologies. Grey shading indicates where results are not significant at $p<0.05$ as evaluated with a Student's $t$ test using 10 years of data for the 2090s (RCP 8.5) and present-day simulations.

of the four CCMs) were also used for qualitative attribution purposes.

\section{CO-tracer redistribution in response to climate change}

The distribution of the $\mathrm{CO}$ tracer in the troposphere under present-day conditions and its redistribution under the RCP 8.5 climate scenario are now discussed. Similarities and differences across the four CCMs and with season are highlighted. Note that the monthly average atmospheric burden of the CO tracer is nearly identical for the 2000s and 2090s, as expected given the specified emissions and lifetime, so that the differences in mixing ratio discussed here result purely from a redistribution due to changes in transport.

\subsection{Present-day distributions}

For the present-day period (1995-2006), the CO-tracer distributions show the effect of deep convection in the tropics and synoptic and convective lifting over mid-latitudes.
There is a strong seasonality in the CO-tracer distributions, which is driven by both the seasonality of $\mathrm{CO}$ source emissions (Fig. 1) and seasonal changes in transport. In the tropics, the largest CO-tracer mixing ratios occur during boreal winter (DJF), hereinafter winter (Fig. 2), compared to boreal summer (JJA), hereinafter summer (Fig. 3). In the northern mid-latitudes, CO-tracer mixing ratios are largest in boreal spring and in the southern mid-latitudes in boreal autumn. Elsewhere CO-tracer mixing ratios have a fairly uniform seasonal cycle.

During winter, large CO-tracer mixing ratios are found near the Equator, with decadal-average values of more than $60 \mathrm{ppb}$ extending from the surface to $\sim 700 \mathrm{hPa}$ and up to $40 \mathrm{ppb}$ in the mid-upper tropical troposphere in all four CCMs (Fig. 2). In summer, CO-tracer mixing ratios are lower in the tropics and northern extratropics extending to $\sim 40^{\circ} \mathrm{N}$ $(\sim 40-50 \mathrm{ppb}$ at the surface and $30-40 \mathrm{ppb}$ in the mid- to upper troposphere in the Northern Hemisphere; Fig. 3) than in winter (Fig. 2). In contrast, in the northern middle and high latitudes, CO-tracer mixing ratios are higher in summer (up to $50 \mathrm{ppb}$ near the surface; Fig. 3) than in winter 


\section{JJA}

(a) UM-CAM
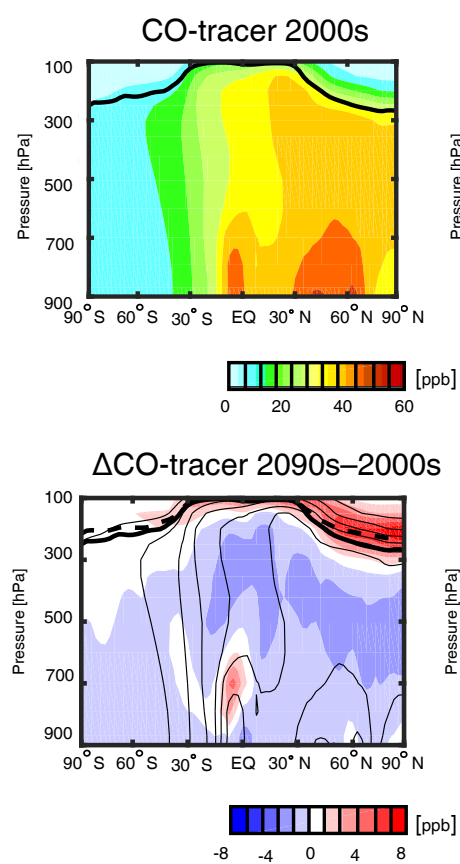

(b) STOC-HadAM3
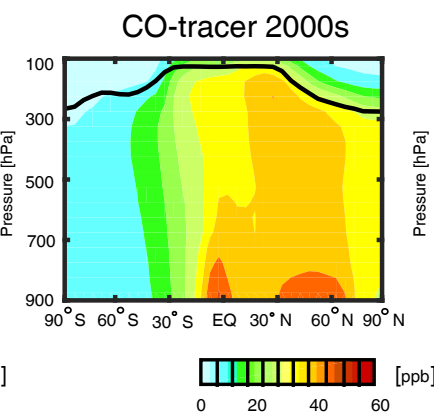

$\Delta$ CO-tracer 2090s-2000s

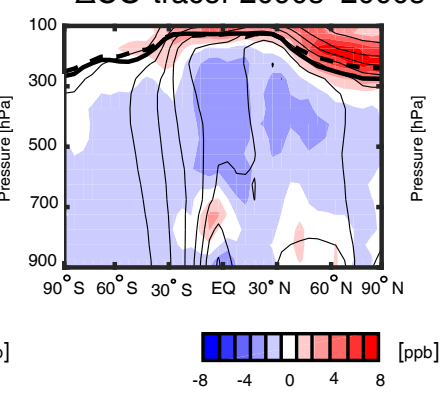

(c) CMAM

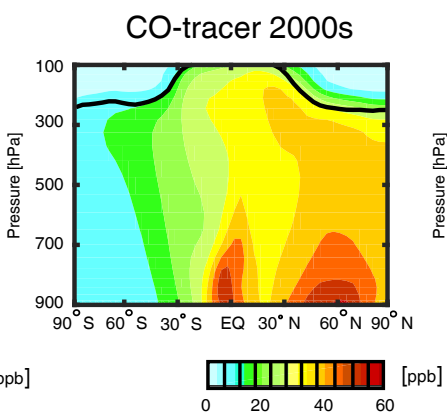

(d) GISS-E2-R

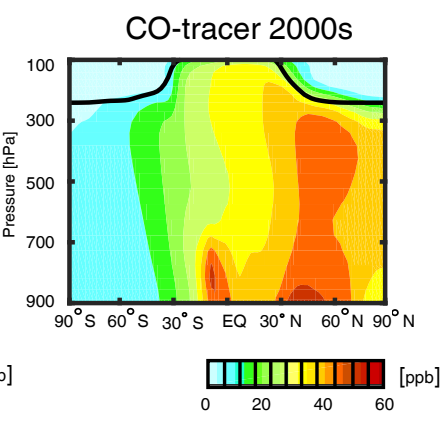

Figure 3. Same as Fig. 2 but for boreal summer (JJA).

(Fig. 2). Note that, while the CO-tracer distribution patterns are fairly similar between the models, there are some differences. In particular, CMAM simulates slightly lower values in the tropical upper troposphere in winter compared to the other CCMs (Fig. 2c), while the GISS-E2-R simulation features larger values above $700 \mathrm{hPa}$ over northern mid-latitudes during summer (Fig. 3d).

The spatial pattern of the $\mathrm{CO}$ tracer averaged over the lower to mid-troposphere $(400-800 \mathrm{hPa}$; Fig. 4) is zonally relatively uniform in winter and is similar across the four CCMs. This pattern also highlights the influence of strong vertical transport in the tropics and subsequent horizontal transport of the $\mathrm{CO}$ tracer from its major anthropogenic surface sources over East and South Asia as well as biomass burning sources in equatorial and Central Africa. During summer, the lower- to mid-tropospheric CO-tracer patterns are more closely confined to the source region locations over East and South Asia and Central Africa (Fig. 5) suggesting weaker transport around the middle troposphere than in winter.

The seasonal differences in CO-tracer mixing ratios in the tropics reflect the combined influence of seasonal differences in biomass burning emissions and in tropical convection. In particular, during winter, when the ITCZ is located in the Southern Hemisphere, the largest emissions from biomass burning originate over Africa near the Equator (Fig. 1). In contrast, during summer, when the ITCZ is located north of the Equator, the peak biomass burning emissions are located further southward $\left(\sim 20^{\circ} \mathrm{S}\right)$ (Fig. 1). Thus, in summer tropical convection is weakly co-located with biomass burning emissions, resulting in lower $\mathrm{CO}$-tracer mixing ratios in the tropical mid-troposphere as a whole and a more confined region of peak CO-tracer mixing ratios over Central Africa (Fig. 5), compared to winter (Fig. 4). The influence of the ITCZ position is also seen in the $\mathrm{CO}$-tracer vertical gradient (the ratio of the $\mathrm{CO}$ tracer relative to its value at the surface) which is shallower in the southern tropics during winter and in the northern tropics in summer (not shown) due to greater vertical mixing from convective lofting along the ITCZ (Sect. 4.1). Note that seasonal differences related to the transport of anthropogenic sources in the mid-latitudes may also be important, with strong surface lofting in winter storm tracks resulting in larger CO-tracer mixing ratios over the northern extratropics during winter (Fig. 4) than in summer (Fig. 5).

Note that the CO-tracer mixing ratios in this study are higher than those reported by Fang et al. (2011) since we use a longer lifetime of 50 days rather than 25 days. CO-tracer mixing ratios are typically lower than modelled or observed real CO (which is usually more than 100 ppb over source re- 
(a) UM-CAM
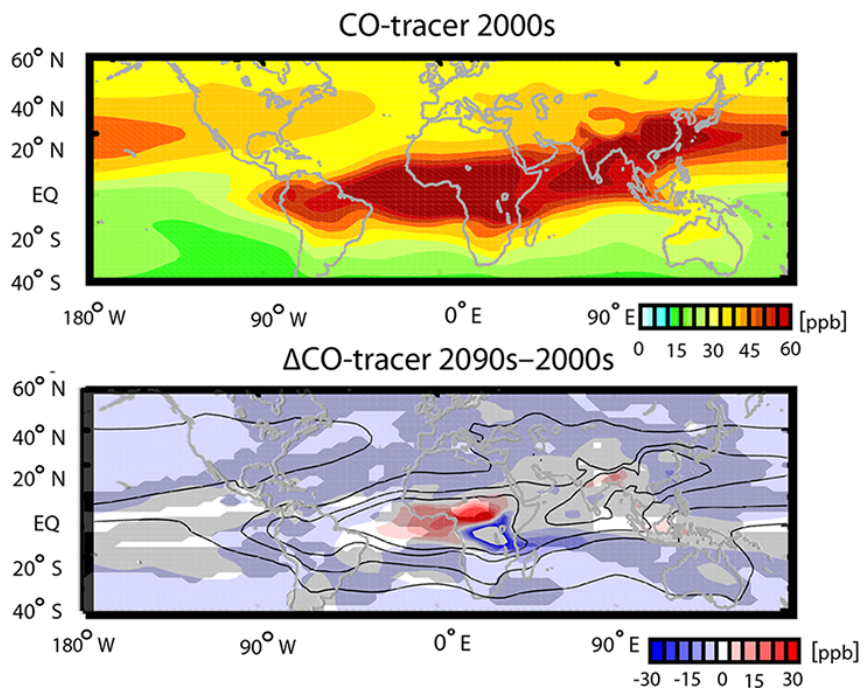

(c) CMAM
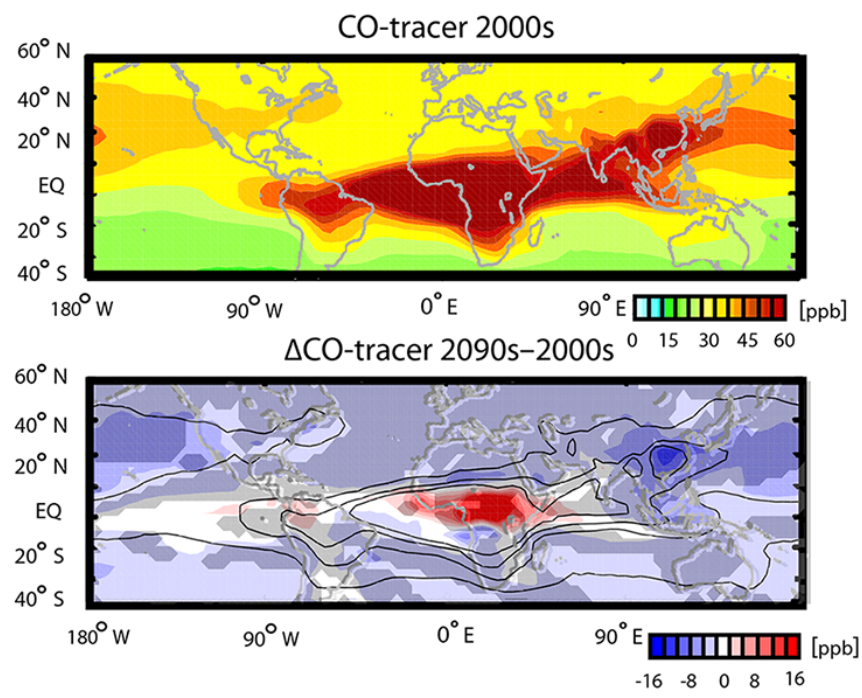

(b) STOC-HadAM3
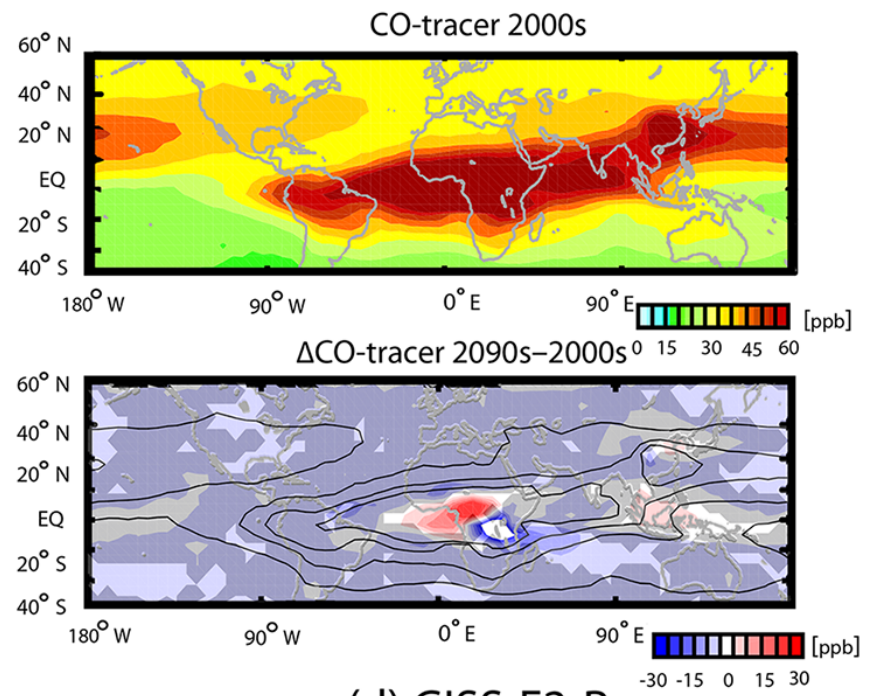

(d) GISS-E2-R
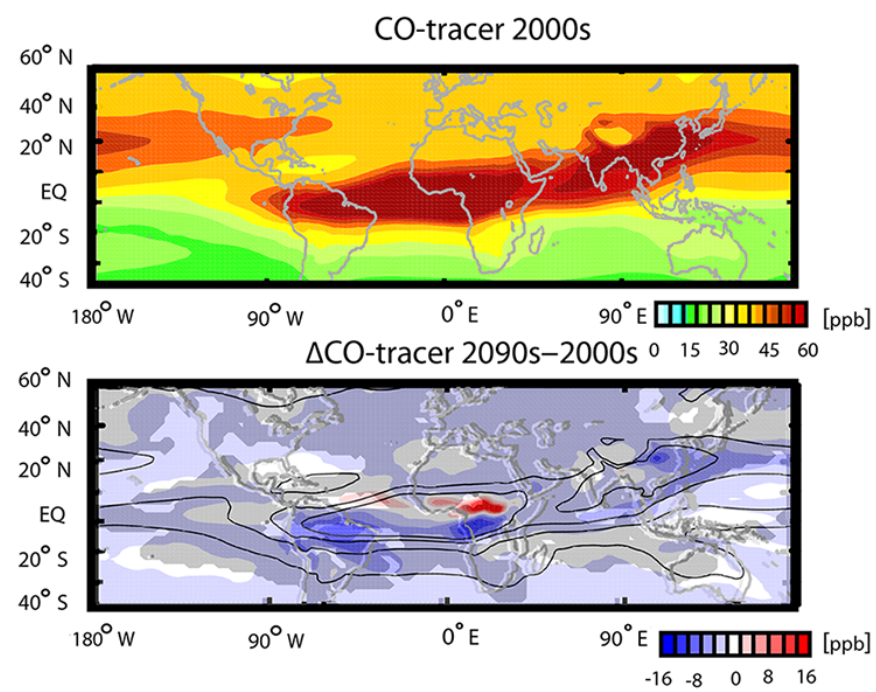

Figure 4. Top panels within subplots (a-d): present-day (1995-2006) DJF 10-year climatological mean CO-tracer distribution, averaged over 400-800 hPa. Bottom panels: differences between 2090-2099 (RCP 8.5) and 1995-2006 (present day) DJF climatological mean CO-tracer distributions, wherein black contours denote the present-day climatology. Results are presented for (a) UM-CAM and (b) STOC-HadAM3 (top panels) as well as (c) CMAM and (d) GISS-E2-R (bottom panels). Grey shading indicates where results are not significant at $p<0.05$ as evaluated with a Student's $t$ test using 10 years of data for the 2090s (RCP 8.5) and present-day simulations. Note the different scales for (i) UM-CAM and STOC-HadAM3 and (ii) CMAM and GISS-E2-R for the difference plots.

gions) as there is no chemical production of the $\mathrm{CO}$ tracer, which accounts for about half of atmospheric CO (Shindell et al., 2006). The seasonality of the $\mathrm{CO}$ tracer and $\mathrm{CO}$ is fairly similar, with a more pronounced winter peak in the tropics in the $\mathrm{CO}$ tracer in the mid-troposphere. The relative changes in $\mathrm{CO}$-tracer mixing ratios are largest in the tropics and during winter and smaller in summer. Henceforth, the focus is on findings for boreal winter and summer.

\subsection{Response to greenhouse gas increases}

The response of CO-tracer mixing ratios to climate change shows robust features that are statistically significant across the four CCMs (Figs. 2 and 3). This suggests a general consistency in changes in transport between 1995-2006 and 2090-2099 under the RCP 8.5 climate scenario. In general, in both winter and summer, CO-tracer mixing ratio decreases are ubiquitous throughout most of the troposphere. 


\section{(a) UM-CAM}
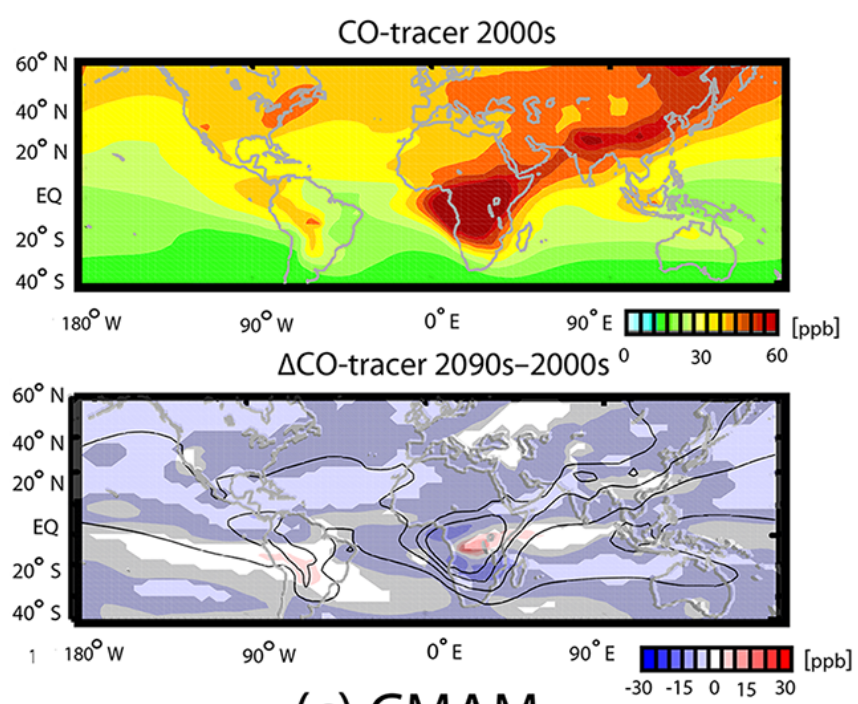

(c) CMAM
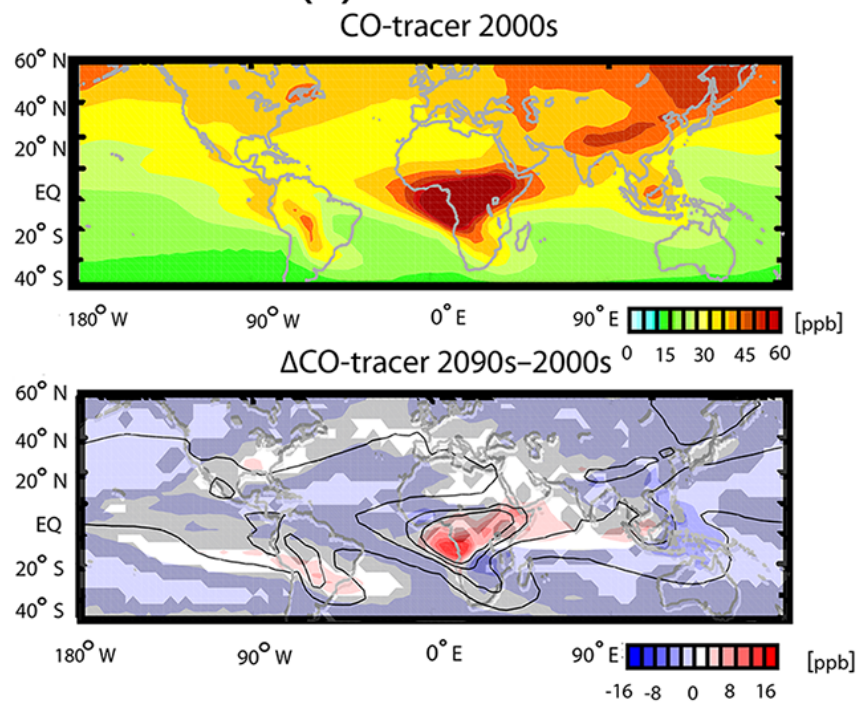

JJA

(b) STOC-HadAM3
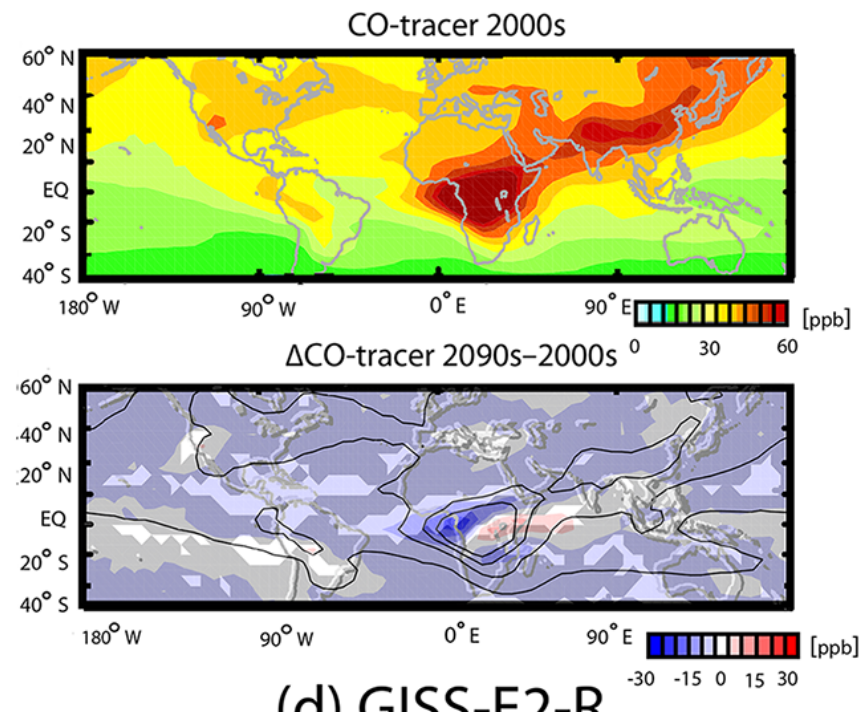

(d) GISS-E2-R

CO-tracer 2000s
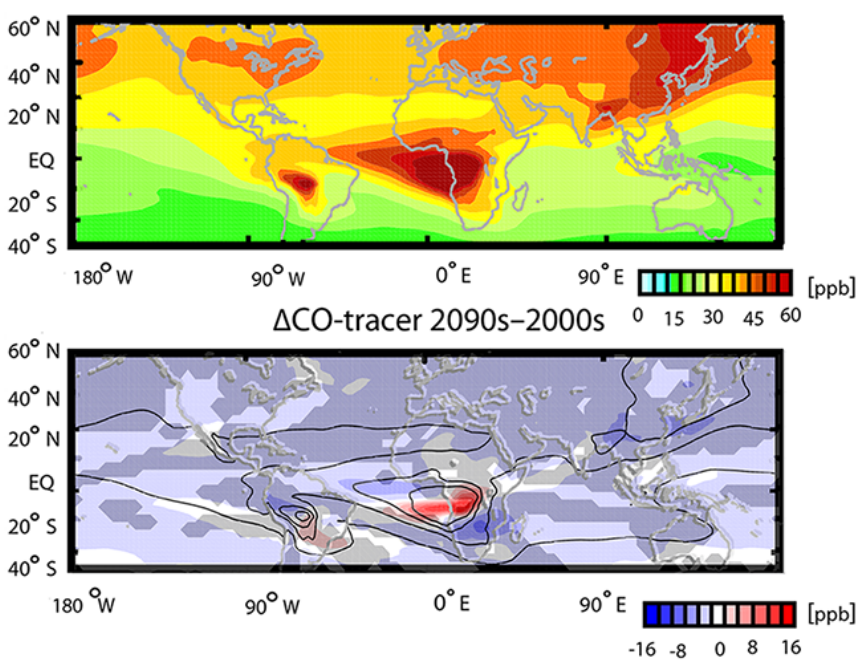

Figure 5. Same as Fig. 4 but for JJA. Note the different scales for (i) UM-CAM and STOC-HadAM3 and (ii) CMAM and GISS-E2-R for the difference plots.

The largest changes occur in boreal winter, with decreases of $\sim 2-6 \mathrm{ppb}(\sim 5-10 \%)$ in CO-tracer mixing ratios near the surface at the Equator, and especially in the middle to upper tropical troposphere in the tropics and the northern mid-latitudes (Fig. 2). In contrast, there is a narrow region of increases in CO-tracer mixing ratios of up to $6 \mathrm{ppb}$ $(\sim 10 \%)$ at $\sim 5-10^{\circ} \mathrm{N}$ reaching from the surface to the midtroposphere (and into the upper troposphere in CMAM). This feature is also seen in the annual-mean CO-tracer distributions for the four CCMs (not shown). Fang et al. (2011) also find substantial decreases in annual-mean CO-tracer concentrations in the free troposphere $(-2$ to $-12 \%$ at $400 \mathrm{hPa})$ but more widespread increases $(2-7 \%)$ in annual-mean COtracer mixing ratios near the surface that extend from the Equator to the northern mid-latitudes. Since the same emission data are used in both studies, this difference is likely to arise from differences in CO-tracer lifetime used as well as model differences in representing shallow convection and/or advection processes.

Future CO-tracer mixing ratios also increase substantially by $\sim 2-6 \mathrm{ppb}(\sim 10-25 \%)$ near the present-day tropopause and into the lower stratosphere (where the relative changes can reach $50 \%$ ), especially in the tropics and northern midlatitudes in all the CCMs (Fig. 2). The contribution of the 
rise in the tropopause to the increase in CO-tracer mixing ratios is explored further in Sect. 4.2. This near-tropopause increase in CO-tracer mixing ratios in the northern mid- to high latitudes is also consistent with future increases in poleward transport reported by Orbe et al. (2015) based on tracers of air-mass origin. Increases in the vertically integrated CO-tracer column between the 2000s and 2090s between 30 and $40^{\circ} \mathrm{N}$ in all models also suggest an increase in advective transport poleward, since vertical redistribution alone would not produce an increase in the vertical column. Similar difference patterns occur in summer, except that the narrow region of increase is above the surface, is smaller in magnitude and vertical extent, and is centred south of the Equator, where present-day CO-tracer concentrations peak (coinciding with the summer biomass burning peak) (Fig. 3). The fractional or relative changes in CO-tracer concentrations between winter and summer are fairly similar (not shown).

Examining the spatial changes in tropical CO-tracer concentrations in the lower to mid-troposphere in relation to the future increases and decreases described above, a clear dipole pattern emerges across all four CCMs (Figs. 4 and 5). In particular, during winter, there is a large increase centred over equatorial and Central Africa (the regions with peak biomass burning) and a decrease south of this of similar magnitude of $\sim 15 \mathrm{ppb}$ (and up to $30 \mathrm{ppb}$ for the region of decrease in UM-CAM and STOC-HadAM3) (Fig. 4). The area of increase coincides with the increase near the Equator extending from the surface to the mid-troposphere, seen in Figs. 2 and 3 described above. This dipole pattern reflects stronger confinement of $\mathrm{CO}$-tracer mixing ratios near regions of emissions, flanked by smaller concentrations downwind to the south. Note that, while the zonally varying pattern of the response in the $\mathrm{CO}$ tracer is characterised by high internal variability, this dipole pattern is statistically significant across most of its extent in all of the CCMs. However, there are small differences across models. Similar patterns of change are simulated by the UM-CAM and STOC-HadAM3 CCMs (Figs. $4 \mathrm{e}-\mathrm{f}$ and $5 \mathrm{e}-\mathrm{f}$ ) since they use the same driving GCM. A stronger and more extensive area of increase and a weaker area of decrease is simulated by the CMAM model in both seasons (Figs. 4c and 5c), while GISS-E2-R simulates a weaker area of increase and a more extensive area of decreases that extends latitudinally across to South America in winter (Figs. 4d). Both CMAM and GISS-E2-R also depict an area of decrease over East Asia, although these changes are not statistically significant.

\section{Potential drivers of changes in transport in a future climate}

The impact of climate change under the RCP 8.5 scenario on deep convection and on jet stream locations is outlined here in relation to the seasonal CO-tracer redistributions described above. The increase in tropopause height under $\mathrm{CO}_{2}$ warm- ing and its influence on CO-tracer distributions is also elucidated. Modifications to these transport processes have implications for pollutant transport from major source regions in the future.

\subsection{Convection and jet streams}

The meteorological and physical drivers of the $\mathrm{CO}$ tracer mixing ratios and changes due to climate change are examined using data from the four ACCMIP model simulations. For present day, during both winter and summer, deep convection in the tropics extends from the surface to $\sim 300 \mathrm{hPa}$ or higher in all four CCMs (Figs. 6 and 7). While the magnitude of the parameterised convective mass fluxes simulated by CMAM and especially the GISS-E2-R CCM (up to $30 \times 10^{-3} \mathrm{~kg} \mathrm{~m}^{-2} \mathrm{~s}^{-1}$ ) is larger than for UM-CAM and STOC-HadAM3, which are driven by the same GCM (up to $8 \times 10^{-3} \mathrm{~kg} \mathrm{~m}^{-2} \mathrm{~s}^{-1}$ ), the spatial patterns and seasonality of convection are consistent across all models (Figs. 6 and 7). For example, in the tropics and subtropics, the strongest convective mass fluxes shift location from $10-20^{\circ} \mathrm{S}$ in winter to $10-20^{\circ} \mathrm{N}$ in summer as the ITCZ migrates south and northwards of the Equator. Convective mass fluxes are also large in the northern mid-latitudes in winter and in the southern mid-latitudes in summer when the mid-latitude jet streams are strongest, but their vertical extent is shallower than in the tropics. Substantial differences of a factor of 2-3 in annualmean zonal convective mass fluxes simulated across three models (including STOC-HadAM3) were also reported in Doherty et al. (2005). Since the same parameterisation is used by UM-CAM, HadAM3, and GISS-ER-2, it may be the specific details of its implementation and interactions with internal parameters (Scinocca and McFarlane, 2004) that cause this large difference in magnitudes across the four CCMs.

The spatial patterns of convective mass fluxes averaged over the lower to upper troposphere ( 800 to $300 \mathrm{hPa}$ ) highlight the zonal symmetry of deep convection across the ITCZ and depict the seasonal migration of the ITCZ within the subtropics (Figs. 8 and 9). Hence, as discussed in Sect. 3.1, the large CO-tracer mixing ratios over equatorial and Central Africa during winter (Fig. 4) reflect the strong co-location of biomass burning emissions and convection in the Southern Hemisphere subtropics when the ITCZ has shifted south of the Equator. By comparison, lower CO-tracer mixing ratios over equatorial Africa during summer reflect both a southward migration in emissions and a northward migration of the ITCZ, resulting in weaker convective lofting in this region (Fig. 5). The larger CO-tracer mixing ratios at higher altitudes over northern mid-latitudes during summer simulated by the GISS-E2-R CCM (Fig. 2d) may be related to stronger convective mass fluxes at this altitude (Fig. 7d).

A robust feature across all of the models is an overall reduction in convection, as reported by Held and Soden (2006), in response to climate change in the 2090s throughout most 


\section{DJF}

(a) UM-CAM

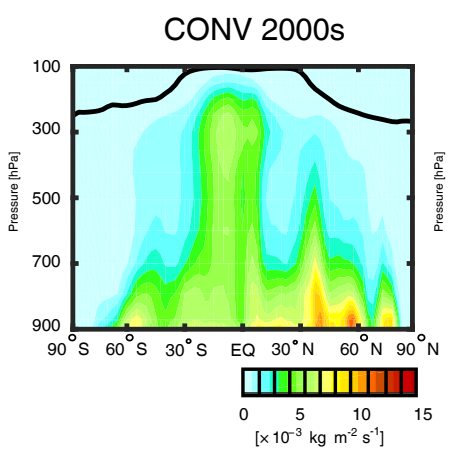

$\triangle$ CONV 2090s-2000s

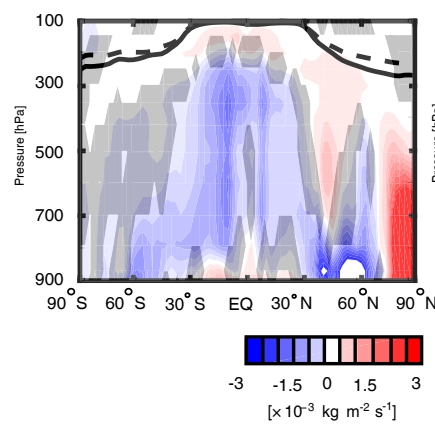

(b) STOC-HadAM3

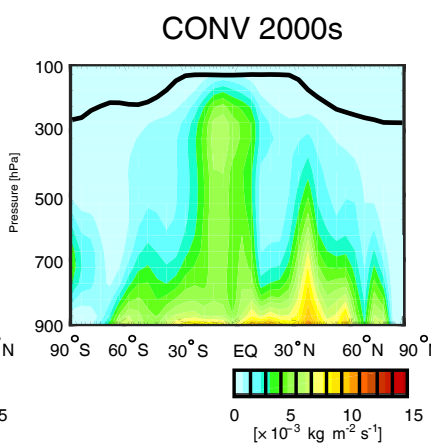

$\triangle$ CONV 2090s-2000s

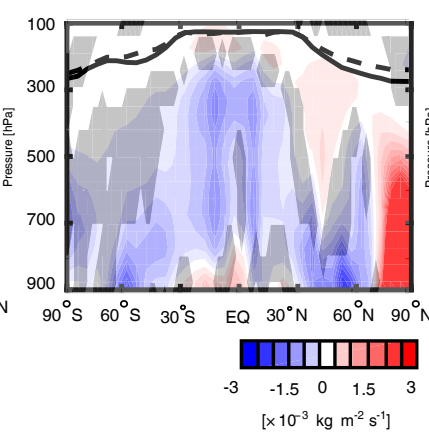

(c) CMAM

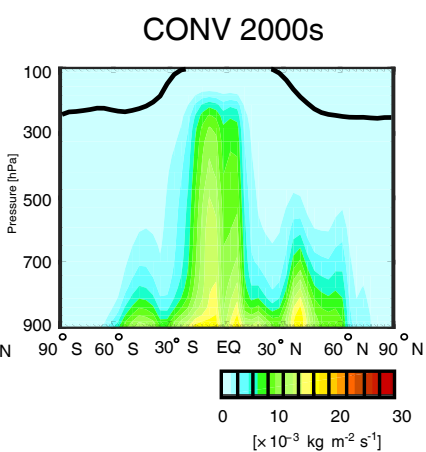

$\triangle$ CONV 2090s-2000s

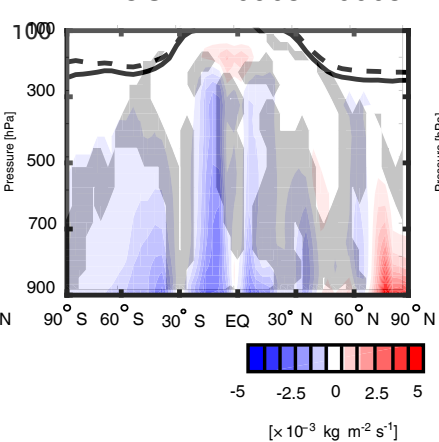

(d) GISS-E2-R

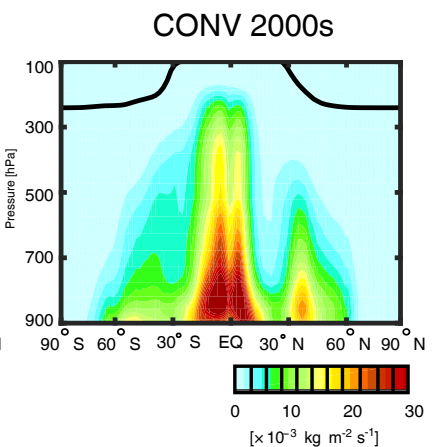

$\Delta$ CONV 2090s-2000s

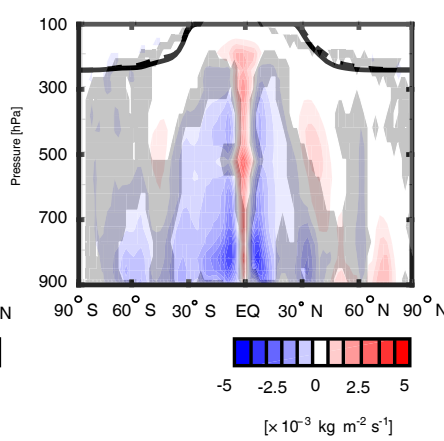

Figure 6. Top panels: DJF 10-year climatological mean zonally averaged convective mass fluxes for present day (1995-2006) for (a) UMCAM, (b) STOC-HadAM3, (c) CMAM, and (d) GISS-E2-R. The thick black solid line represents the present-day (DJF) zonally averaged thermal tropopause. Bottom panels: differences between 2090-2099 (RCP 8.5) and 1995-2006 (present day) DJF climatological mean zonalmean convective mass fluxes. The thick solid and dashed lines represent the DJF zonally averaged thermal tropopause for the present day and the 2090s (RCP 8.5) climatologies. Grey shading indicates where results are not significant at $p<0.05$ as evaluated with a Student's $t$ test using 10 years of data for the 2090s (RCP 8.5) and present-day simulations. Note the different scales for (i) UM-CAM and STOC-HadAM3 and (ii) CMAM and GISS-E2-R.

of the troposphere in both winter and summer (up to 3$5 \times 10^{-3} \mathrm{~kg} \mathrm{~m}^{-2} \mathrm{~s}^{-1} ; \sim 10-30 \%$ ) that is slightly larger for UM-CAM and STOC-HadAM3 than the other two CCMs (Figs. 6 and 7). Absolute and relative changes in convective mass fluxes between winter and summer are similar (not shown). This reduction occurs both in the tropics and in the extratropics, extending to about $40^{\circ} \mathrm{N}$ and $40^{\circ} \mathrm{S}$. The UMCAM and STOC-HadAM3 CCMs also feature strong decreases in convection centred at $60^{\circ} \mathrm{N}$ and $60^{\circ} \mathrm{S}$ extending vertically from the surface to $700 \mathrm{hPa}$ in both seasons. The spatial pattern of the magnitude of convective mass fluxes averaged over the mid-upper troposphere shows the largest decreases occurring along the ITCZ (including the ITCZ portion over Africa) in both seasons for all CCMs (Figs. 8 and 9).

Although convective mass fluxes predominately decrease under greenhouse gas warming, there are small areas of increase. Close to the surface in the tropics increases in convec- tive mass fluxes are simulated by the UM-CAM and STOCHadAM3 CCMs, but not by the other two CCMs (Figs. 6a-b and 7a-b). The GISS-E2-R CCM depicts a small band of increased convective mass fluxes at the Equator extending from the surface to the upper troposphere in winter. A strong increase in convective mass fluxes in the Northern Hemisphere polar latitudes at the surface extending upwards is also a consistent model feature in winter, which is most prominent in UM-CAM and STOC-HadAM3. Since this region is not colocated with major emissions, these increases in convection have a very small influence on the CO-tracer distributions. Increases in convective mass fluxes are also simulated over the east Pacific portion of the ITCZ by GISS-E2-R and, to a lesser extent, by the CMAM model (Figs. 8c-d and 9cd). Again, since this area of increase is over the ocean and hence not co-located with emissions, there is little influence on the spatial patterns of $\mathrm{CO}$-tracer concentration changes (Figs. 4c-d and 5c-d). 
(a) UM-CAM

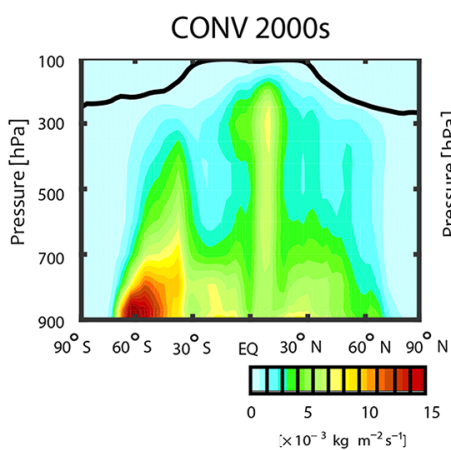

$\Delta$ CONV 2090s-2000s

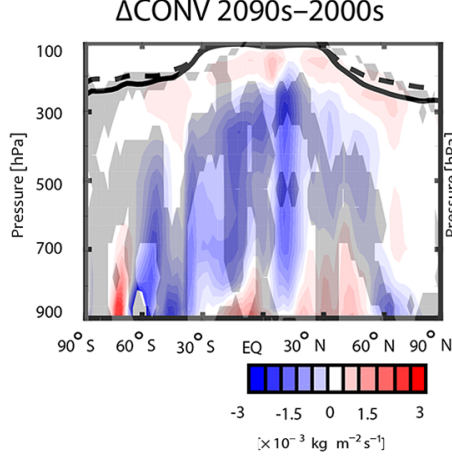

(b) STOC-HadAM3

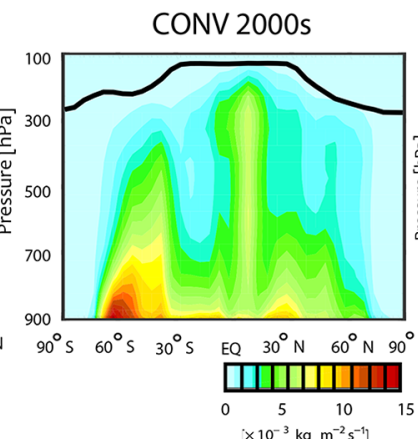

$\Delta$ CONV 2090s-2000s

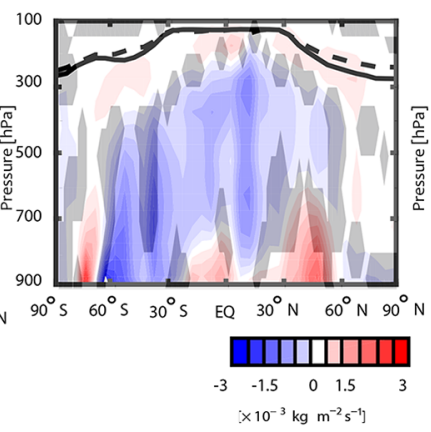

(c) CMAM
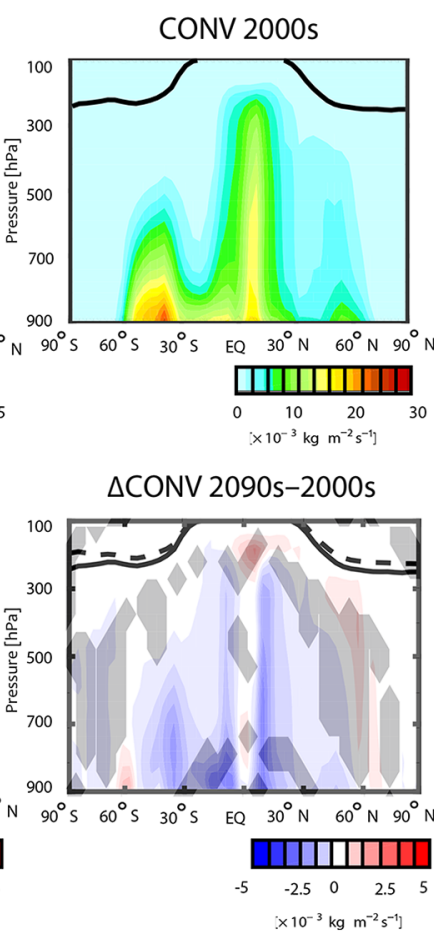

(d) GISS-E2-R
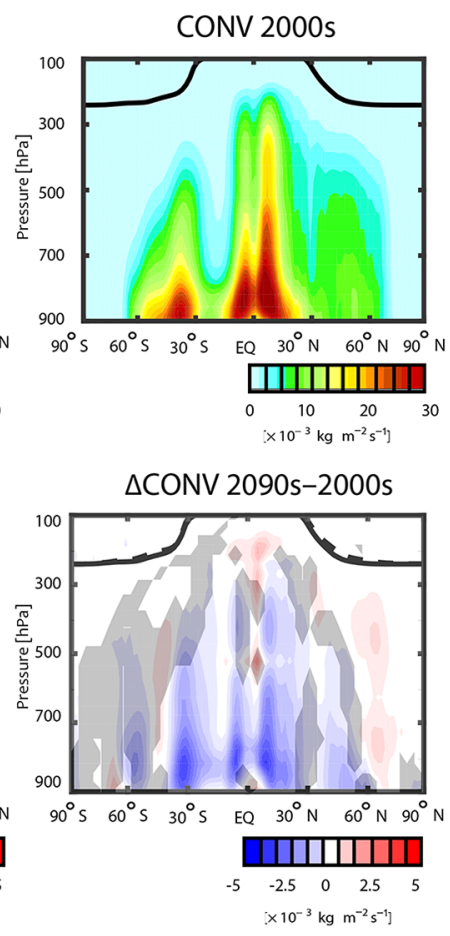

Figure 7. Same as Fig. 6 but for JJA. Note the different scales for (i) UM-CAM and STOC-HadAM3 and (ii) CMAM and GISS-E2-R.

The decrease in convective mass fluxes in the tropics under climate change described above is consistent with the reduced convective lofting of biomass burning emissions and, hence, decreased CO-tracer mixing ratios in the tropical midto upper troposphere in all of the CCMs. Furthermore, reduced convection in the tropics may also explain the dipole pattern of change in $\mathrm{CO}$-tracer mixing ratios over equatorial and Central Africa in the lower to mid-troposphere through greater confinement of CO-tracer concentrations to the region directly aloft of the surface emissions source (Figs. 4 and 5). These changes in CO-tracer concentrations are primarily determined by the extent of co-location between convective and biomass burning source regions and how convection changes over these emission source regions.

Reduced convective mass fluxes in the future may also partly explain decreases in CO-tracer concentrations in the mid-latitude mid- to upper troposphere (Figs. 2 and 3), although changes in the mid-latitude storm tracks may also play an important role in modulating the $\mathrm{CO}$-tracer changes at these higher altitudes. In particular, all of the models feature a poleward shift in their zonal-mean zonal winds under climate change, as found in previous studies (e.g. Yin et al., 2005; Orbe et al., 2015), leading to reductions in zonalmean winds in adjacent regions of the mid-latitude tropo- sphere in both seasons, although they are generally largest in winter (Fig. 10). However, although the broad patterns of change in zonal-mean winds are similar, there are different magnitudes and patterns of responses across latitude bands for the different models with UM-CAM and CMAM featuring substantially weaker $\left(\sim 5 \mathrm{~ms}^{-1}\right.$; Fig. 10a-b) zonal-mean winds poleward of $\sim 35^{\circ} \mathrm{S}$ in winter, while the GISS-E2-R CCM shows weaker $\left(5 \mathrm{~ms}^{-1}\right.$; Fig. 10c) zonal-mean winds poleward of $\sim 35^{\circ} \mathrm{N}$ in winter and $\sim 35^{\circ} \mathrm{N}$ in summer. In the tropics, the zonal-mean wind response to climate change is rather variable. Other wind component fields were not archived in the ACCMIP simulations, which prohibits further investigation into the relationship between mid-latitude jet stream changes and CO-tracer responses over the midlatitudes.

\subsection{Tropopause height}

Robust increases in CO-tracer mixing ratios near the tropopause in the tropical and northern mid-latitudes in response to climate change are seen in all four CCMs (Figs. 2 and 3). The annual average multi-model mean tropopause in the 2090s moves upward by $12 \mathrm{hPa}$ in the tropics and $27 \mathrm{hPa}$ in the mid-latitudes relative to its position in the 2000s. 
(a) UM-CAM

CONV 2000s
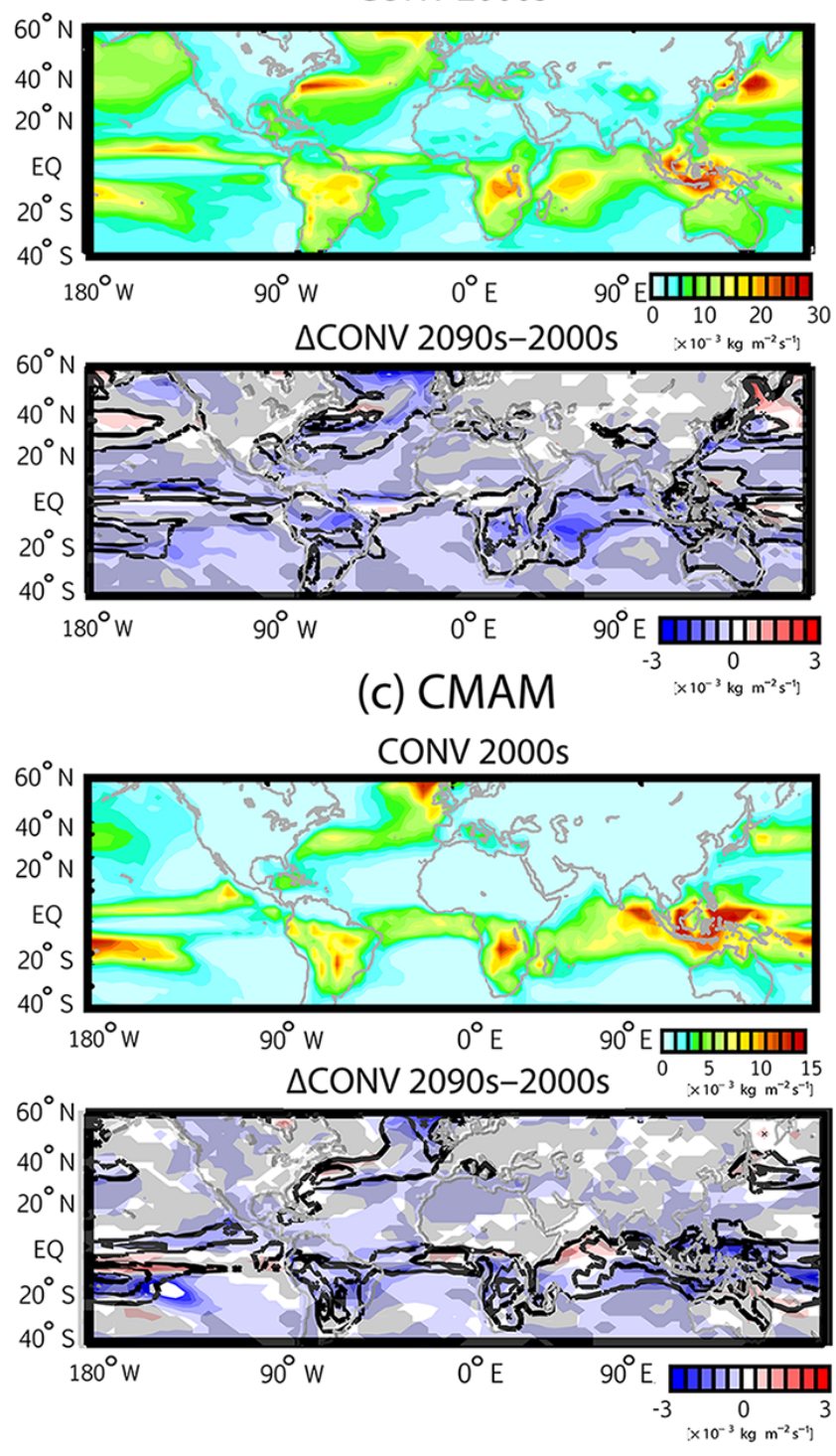

(b) STOC-HadAM3

CONV 2000s
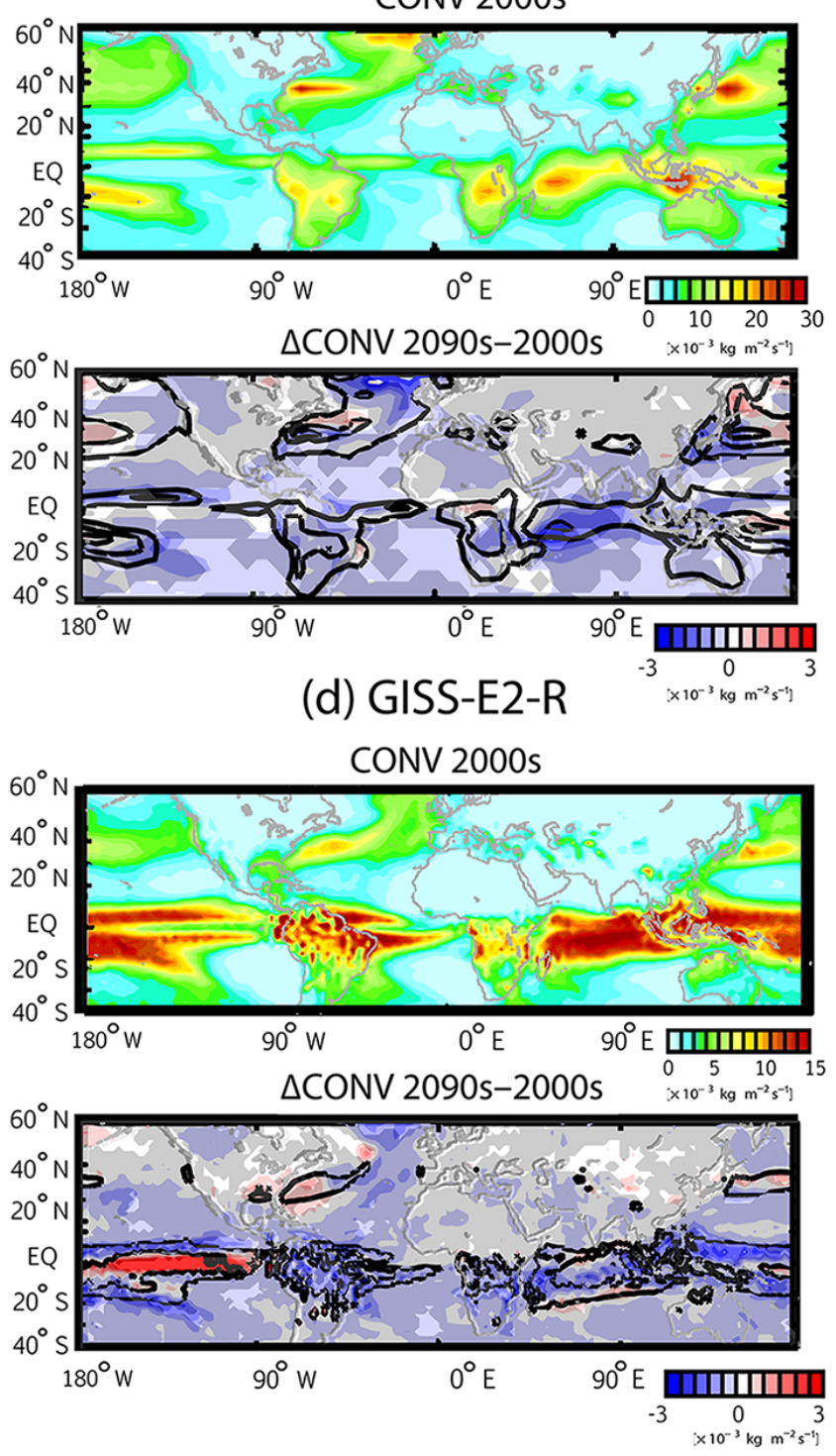

Figure 8. Top panels within subplots (a-d): DJF 10-year climatological mean convective mass fluxes, averaged over 300-800 hPa for 19962005 (present day). Bottom panels: differences between 2090-2099 (RCP 8.5) and 1996-2005 (present day) DJF climatological mean convective mass fluxes, wherein black contours denote the present-day climatology. Results are presented for UM-CAM and STOC-HadAM3 (top panels) and CMAM and GISS-E2-R (bottom panels). Grey shading indicates where results are not significant at $p<0.05$ as evaluated with a Student's $t$ test using 10 years of data for the 2090s (RCP 8.5) and present-day simulations. Note the different scales for (i) UM-CAM and STOC-HadAM3 and (ii) CMAM and GISS-E2-R.

Previous studies have attributed similar CO-tracer changes to changes in tropopause height (Fang et al., 2011), which is a robust feature of greenhouse gas warming (e.g. Kang et al., 2013) and shown by all four CCMs.

Following Fang et al. (2011), we elucidate the role of an increase in tropopause height in modulating CO-tracer concentrations by comparing annual-mean profiles of the $\mathrm{CO}$ tracer, plotted relative to the thermal tropopause, for both present-day and future periods (Fig. 11). Comparison of annual-mean $\mathrm{CO}$-tracer profiles reveals that when vertical $\mathrm{CO}$-tracer profiles are compared in tropopause relative coordinates there is generally less difference between present day and future, unlike when the CO-tracer profiles are plotted relative to pressure. Therefore, much of the CO-tracer increase near the tropopause that occurs in the future arises from a rise in tropopause height, as reported in Fang et al. (2011) and 
(a) UM-CAM

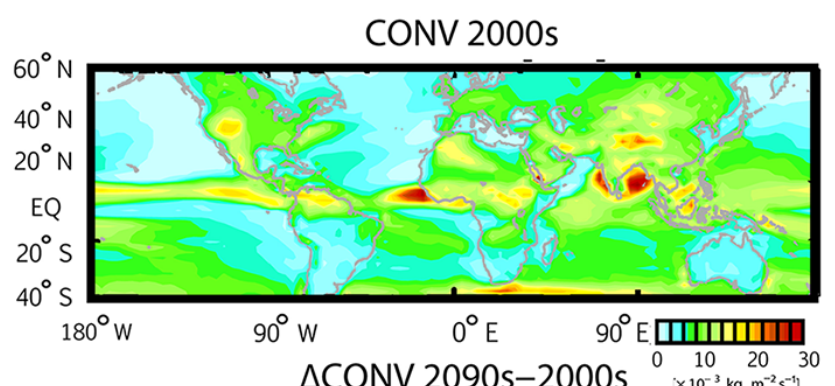

$\Delta$ CONV 2090s-2000s $\stackrel{0}{0} \underset{10^{-3} \mathrm{~kg} \mathrm{~m}^{-2} \mathrm{~s}^{-1 / 1}}{20}$

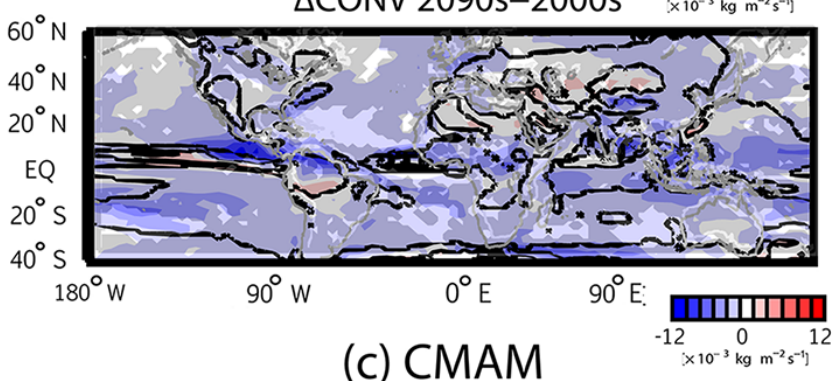

(c) CMAM
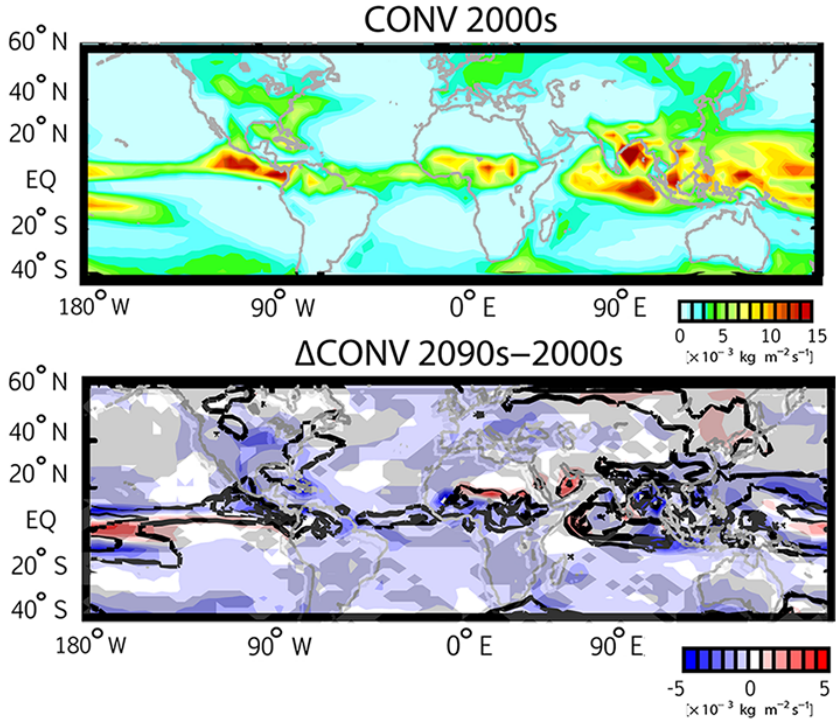

JJA
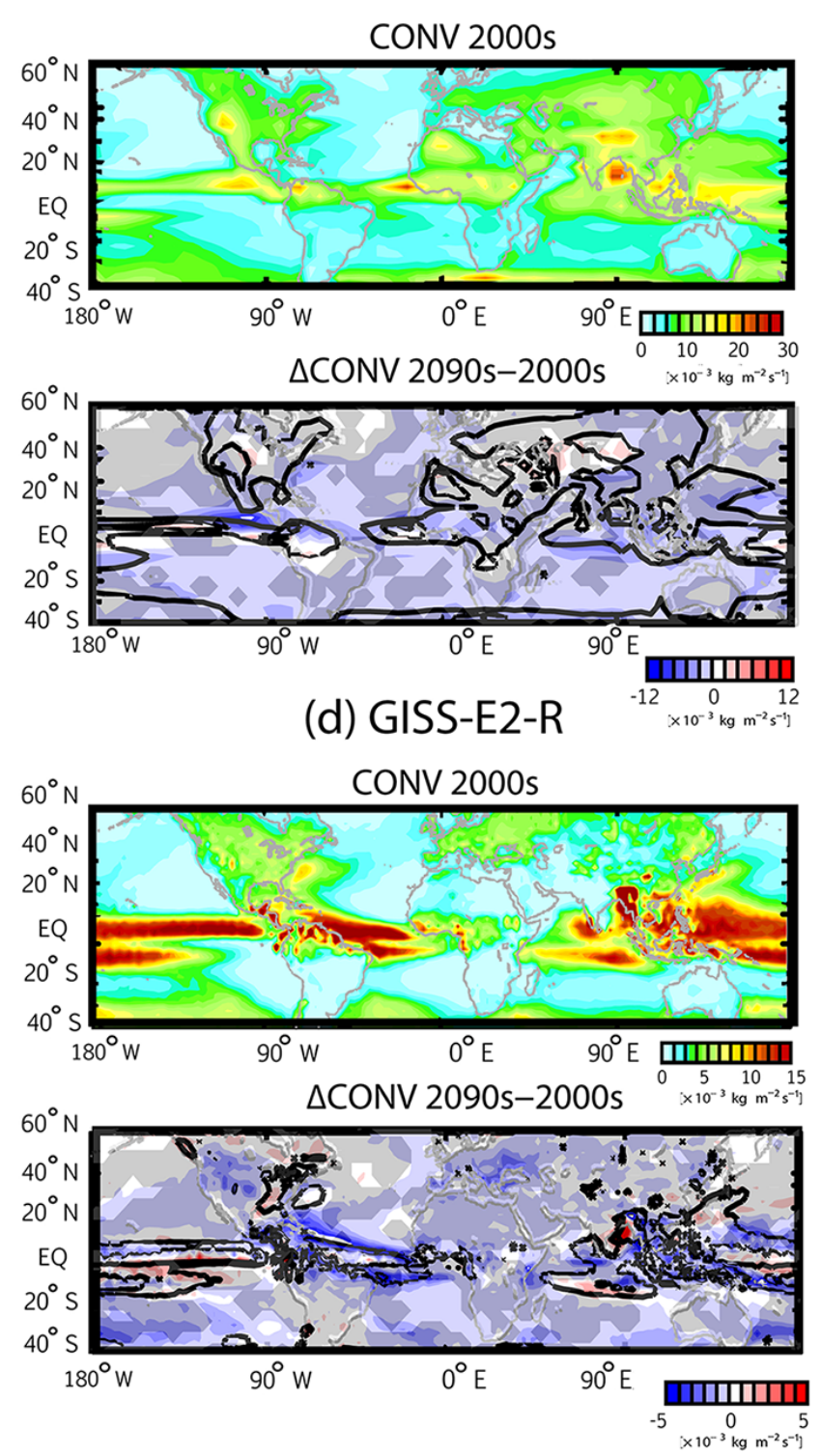

Figure 9. Same as Fig. 8 but for JJA. Note the different scales for (i) UM-CAM and STOC-HadAM3 and (ii) CMAM and GISS-E2-R.

also by Abalos et al. (2017) using the e90 tracer. This is evident for all models, especially in the northern mid-latitudes $\left(40^{\circ} \mathrm{N}\right)$ near the tropopause (Fig. 11). Hence the increase in $\mathrm{CO}$-tracer mixing ratios arises from a transition between low$\mathrm{CO}$ stratospheric air for present day and higher $\mathrm{CO}$ in tropospheric air in the future.

This also suggests that the impacts of enhanced poleward and upward transport in the northern mid-high latitudes near the tropopause on CO-tracer mixing ratios (Sect. 3.2) are largely outweighed by the impact of the rise in the tropopause, although these effects may be interrelated. However, the tropopause relative profiles in the 2090s also show a slightly weaker vertical gradient between the mid-upper troposphere in the $\mathrm{NH}$ extratropics $\left(40^{\circ} \mathrm{N}\right)$ compared to the 2000s (Fig. 11, top panels). This reduced vertical gradient has been noted in previous studies and also related to a rise in tropopause height (Holzer and Boer, 2001). At the same time, a reduced vertical gradient may also reflect an overall increase in eddy mixing associated with the upward and poleward shifts in zonal-mean winds (Wu et al., 2011). Similar transport responses to GHG-induced changes in eddy mixing have been documented in other studies (Orbe et. al. 2015; Abalos et al., 2017). Since changes in eddy mixing near the tropopause are also linked to changes in tropopause height, it is not possible to disentangle the separate imprint of these changes on the $\mathrm{CO}$-tracer distributions. 
(a) UM-CAM/ STOC-HadAM3

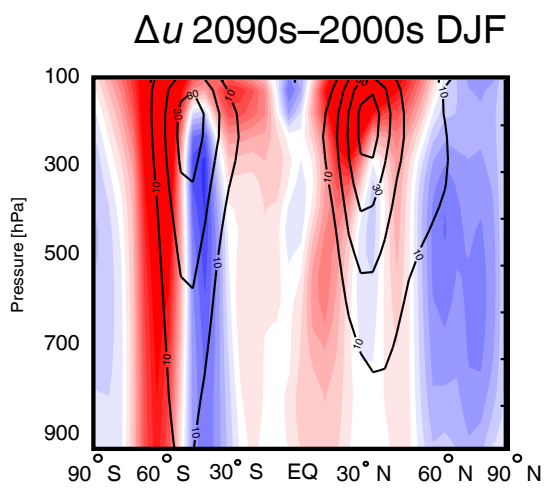

$\Delta u$ 2090s-2000s JJA

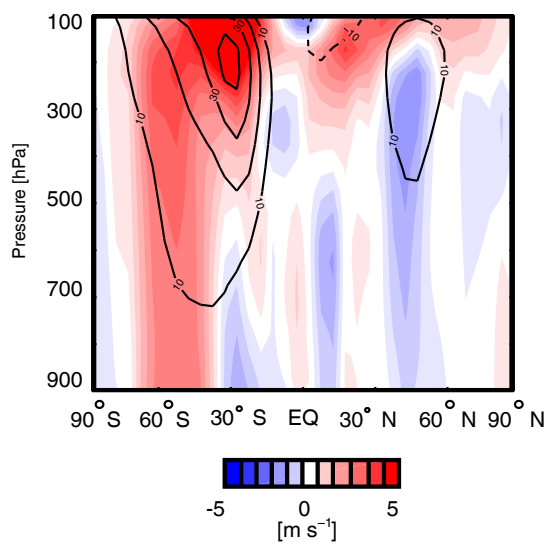

(b) CMAM

$\Delta u$ 2090s-2000s DJF

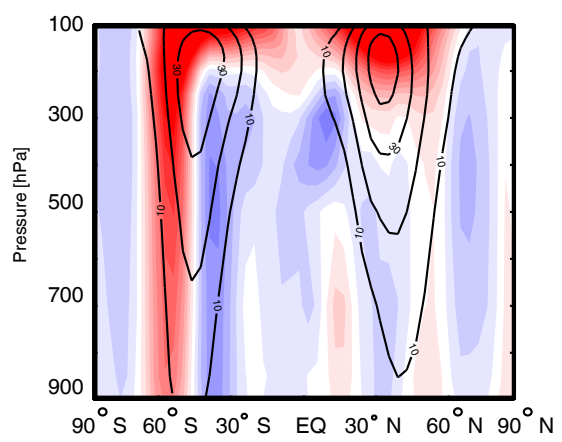

$\Delta u$ 2090s-2000s JJA

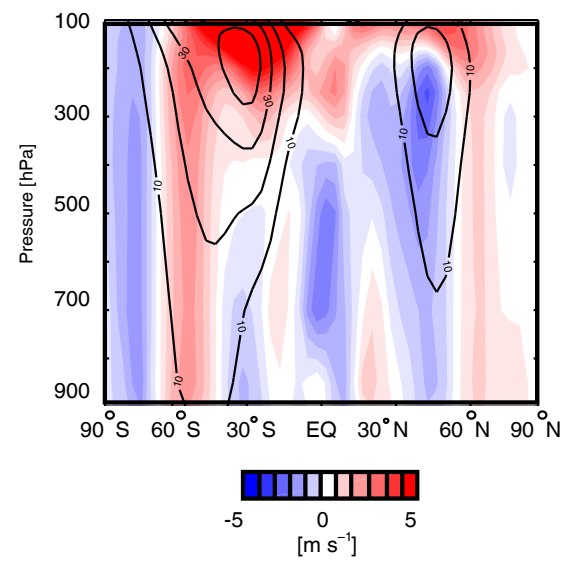

(c) GISS-E2-R

$\Delta u$ 2090-2000s DJF
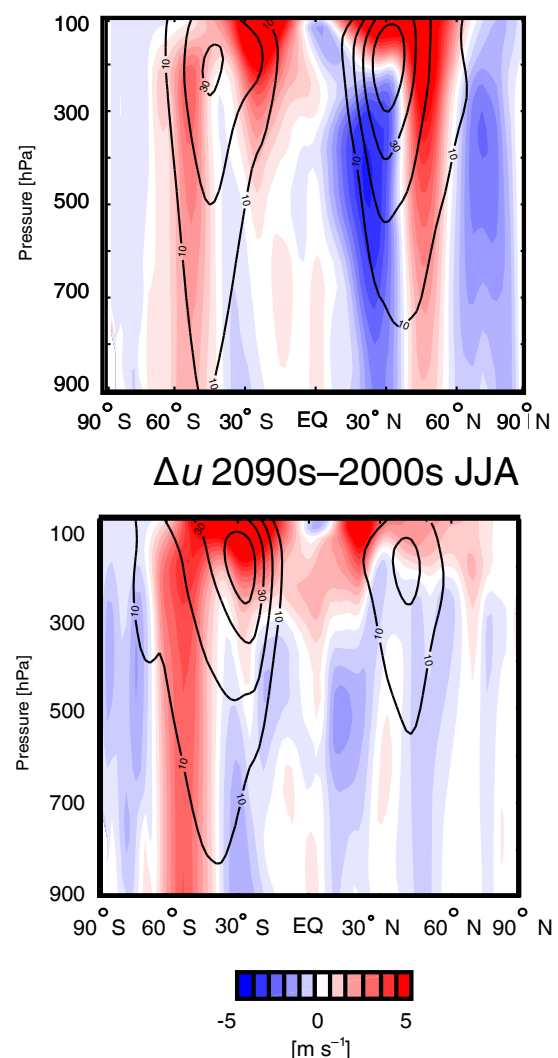

Figure 10. Zonal-mean zonal $(u$ ) wind differences between 2090-2099 (RCP 8.5) and 1996-2005 (present day) for DJF (top panels) and JJA (bottom panels). Results are shown for (a) UM-CAM and STOC-HadAM3 (same driving GCM), (b) CMAM, and (c) GISS-E2-R. Black contours denote the present-day climatology.

\section{Discussion and conclusions}

This study quantifies the seasonal variation and the robustness of changes in transport under climate change. In response to future increases in greenhouse gases in the 2090s under the RCP 8.5 scenario, changes in mixing ratios of a CO-like tracer with a 50-day lifetime exhibit robust features across four chemistry-climate models participating in the ACCMIP model intercomparison. These include a decrease in CO-tracer mixing ratios throughout most of the troposphere, especially in the tropics $(5-10 \%)$, and an increase in CO-tracer mixing ratios near the tropopause (10-25\%), especially over the tropics and northern mid-latitudes. Underlying these changes there is a strong seasonality in transport patterns between winter and summer, with higher COtracer mixing ratios aloft in winter when biomass burning emissions source regions are located along the ITCZ.
These absolute changes in CO-tracer mixing ratios due to climate change are generally larger in boreal winter than in summer, although relative changes are similar. The relative changes in annual-mean CO-tracer mixing ratios at the surface and in the free troposphere are of similar magnitude to those reported by Fang et al. (2011) using the GFDL AM3 model. Somewhat larger decreases in tropospheric-average idealised tracer mixing ratios of $25 \%$ were reported in 2100 by Holzer and Boer (2001) under a different climate change scenario.

In addition, all four CCMs simulate a small region of increase in zonal-mean surface $\mathrm{CO}$-tracer mixing ratios at $\sim 5$ $10^{\circ} \mathrm{N}$ that extends to the mid-troposphere, with decreases southwards, which arise from a dipole pattern of adjacent increases and decreases in CO-tracer mixing ratios over equatorial and Central Africa - the largest biomass burning emission source regions. 
(a)UM-CAM
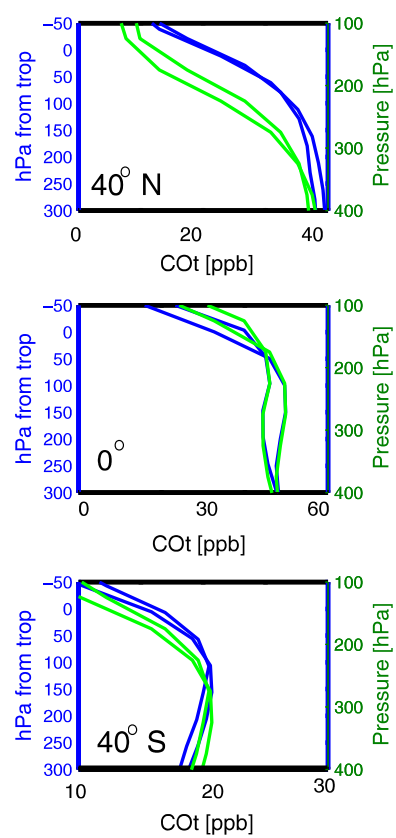

(b) STOC-HadAM3
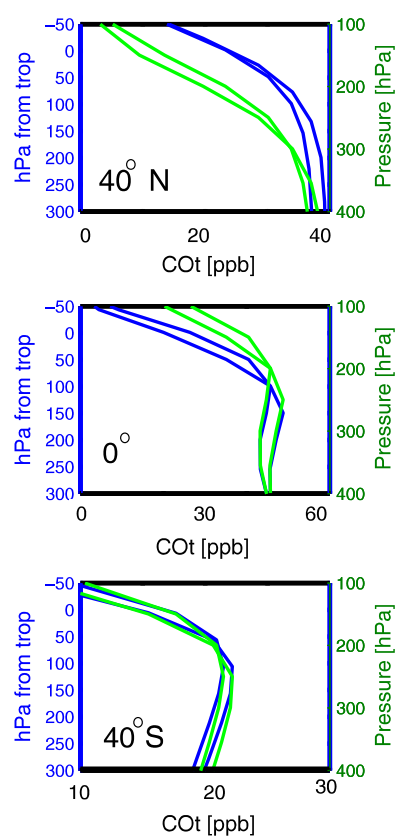

(c) CMAM
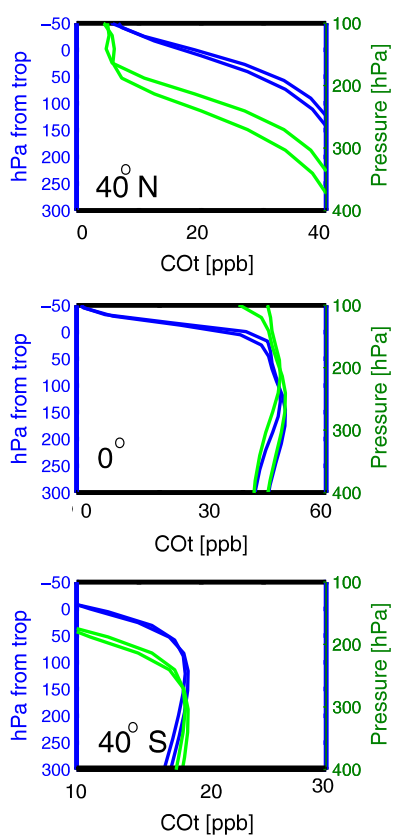

(d) GISS-E2-R
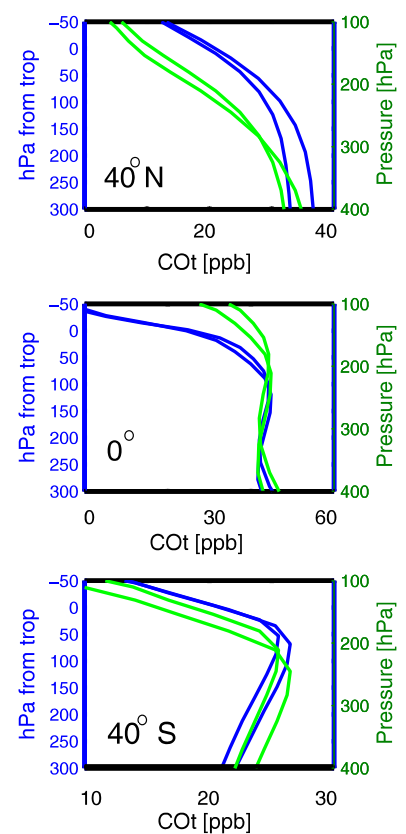

Figure 11. CO-tracer (COt) mixing ratio annual-average profiles (ppb) averaged over various latitude bands $\left(40^{\circ} \mathrm{N}, 0,40^{\circ} \mathrm{S}\right)$ for the $2000 \mathrm{~s}$ (present day) and 2090-2099 (RCP 8.5) for (a) UM-CAM, (b) STOC-HadAM3, (c) CMAM, and (d) GISS-E2-R plotted against altitude in pressure units $(\mathrm{hPa})$ (green) and with distance from the tropopause for the respective time period (blue).

Convective mass fluxes consistently decrease throughout most of the troposphere in the future in all four CCMs in both seasons, with the strongest decreases occurring within the tropics along the ITCZ, in agreement with tropical convective mass flux reductions diagnosed by Held and Soden (2006). However, in contrast to our findings, Abalos et al. (2017) suggests decreases in convection mass fluxes are limited to $\sim 5 \mathrm{~km}$. Decreased convective mass fluxes in our study are consistent with a weakening of the Hadley cell in winter when this feature is robust (Hwan-Seo et al., 2014; Kang et al., 2013; Vallis et al., 2015). The decreases in CO-tracer mixing ratios in the tropical troposphere therefore most likely reflect reduced convection in the future. Reduced convection in the tropics may also explain the dipole in CO-tracer response that occurs near equatorial and Central Africa, since the seasonal patterns of changes in CO-tracer concentrations in the tropics are in essence determined by how seasonal changes in convection project onto seasonally varying biomass burning emissions. Biomass burning emissions were held constant for present day and future in this study.

The higher tropopause reported here is a robust finding across climate change studies (e.g. Kang et al., 2013; Vallis et al., 2015). The strong increases in CO-tracer concentrations in the vicinity of the tropopause can be largely at- tributed to a higher tropopause under greenhouse gas warming, whereby this region has low-CO stratospheric air for present day and higher $\mathrm{CO}$ in tropospheric air in the future, in accord with Fang et al. (2011). A poleward and upward shift in zonal-mean winds is consistent across the four models and noted in previous studies (e.g. Orbe et al., 2015). Resultant enhanced poleward transport may also minorly contribute to CO-tracer increases in the future near the tropopause in the northern mid-latitudes, and changes in eddy mixing may also have an impact. However, all these processes may be interrelated such that it is not possible to discern the impacts of individual processes on CO-tracer mixing ratios.

Overall, large-scale dynamical responses linked to changes in the Hadley cell circulation and their impact on convection, mid-latitude jets, and tropopause height appear to govern the main features of the redistribution of CO-tracer mixing ratios between present day and future simulated by four CCMs in this study. Further diagnostics to allow more detailed dynamical insights would be most useful to probe the relative contributions of different large-scale dynamical processes including stratosphere-troposphere exchange, alongside other aspects of the Hadley circulation such as its broadening or poleward expansion under climate change. 
One further limitation of this study is that the CO-tracer data were not archived at a higher temporal resolution than monthly. Hence, it is not possible to examine how CO-tracer concentrations in the mid-latitudes are influenced by changes in synoptic-scale storm or blocking frequency. Our ability to look further into relationships between the mid-latitude storm tracks and CO-tracer distributions over middle and high latitudes is also limited by the fact that only zonally averaged zonal wind fields were archived. Another limitation is that, while the use of a single tracer emitted from all global $\mathrm{CO}$-sources highlights transport associated with the global continental emission source regions, it precludes an in-depth analysis of regional changes in transport patterns under climate change.

Nevertheless, this multi-model study presents a clear and robust picture of the effect of climate change on the transport of pollution from major emission source regions, in particular from biomass burning regions in the tropics that are strong CO sources, and how this effect varies seasonally as governed by the seasonal location of the ITCZ and biomass burning emissions sources. Furthermore, the key roles of reduced convection consistent with a weakened Hadley circulation in winter and a higher tropopause in governing transport changes are confirmed. Overall, a reduction in tropical deep convection under climate change will confine pollution more closely to its surface source regions, potentially reducing intercontinental transport in upper-level winds aloft. In the mid-latitudes transport of pollution aloft may be impacted by a poleward shift in storm track pathways. Hence, transport changes alone in the absence of stricter emissions controls may reduce future air quality in the vicinity of emission source regions especially in the tropics, due to reductions in vertical transport and dispersion by deep convection. However, this study examines the impacts of climate change on transport alone, whilst future air quality will also be greatly influenced by climate-driven changes in chemistry and by future changes in emissions. Future multi-model comparison studies would benefit from a larger suite of meteorological variables that enable a more detailed diagnosis of the largescale dynamical responses to climate change. Such improved dynamical attribution in tandem with tracer transport studies will enable better quantification of the response of global air pollution transport to greenhouse gas warming.

Data availability. The ACCMIP data used in this study can be obtained from the British Atmospheric Data Centre (BADC) upon request.

Author contributions. RD, CO, GZ, MP, DP, and ML contributed to conception and design. GZ, DP, DS, and IM performed ACCMIP simulations with the UM-CAM, CMAM, GISS-ER-2, and STOCHadAM3 CCMs respectively. CO, RD, GZ, and IM contributed to processing of data. All co-authors contributed to the analysis and interpretation of data. RD and CO drafted the article aided by revisions by GZ, DP, ML, IM, and OW. All co-authors approved the submitted version for publication.

Competing interests. The authors declare that they have no conflict of interest.

Special issue statement. This article is part of the special issue "Global and regional assessment of intercontinental transport of air pollution: results from HTAP, AQMEII and MICS". It is not associated with a conference.

Acknowledgements. Ruth M. Doherty and Ian A. MacKenzie acknowledge the ARCHER UK National Supercomputing Service (http://www.archer.ac.uk) and funding under the UK Natural Environment Research Council grant NE/I008063/1, NE/M003906. Guang Zeng acknowledges the contribution of NeSI high-performance computing facilities to the results of this research. NZ's national facilities are provided by the NZ eScience Infrastructure and funded jointly by NeSI's collaborator institutions and through the Ministry of Business, Innovation \& Employment's Research Infrastructure programme (https://www.nesi.org.nz). ACCMIP is organised under the auspices of Atmospheric Chemistry and Climate (AC\&C), a project of International Global Atmospheric Chemistry (IGAC) and Stratospheric Processes And their Role in Climate (SPARC) under the International Geosphere-Biosphere Programme (IGBP) and World Climate Research Program (WCRP). The authors are grateful to the British Atmospheric Data Centre (BADC), which is part of the NERC National Centre for Atmospheric Science (NCAS), for collecting and archiving the ACCMIP data and to Jean Francois Lamarque for overall ACCMIP coordination.

Edited by: Stefano Galmarini

Reviewed by: three anonymous referees

\section{References}

Abalos, M., Randel, W., Kinnison, D., and Garcia, R.: Using the artificial tracer e90 to examine present and future UTLS tracer transport in WACCM, J. Atmos. Sci., 74, 3383-3403, https://doi.org/10.1175/JAS-D-17-0135.1, 2017.

Allen, R. J., Norris, J. R., and Kovilakam, M.: Influence of anthropogenic aerosols and the Pacific decadal oscillation on tropical belt width, Nat. Geosci., 7, 270-274, https://doi.org/10.1038/ngeo2091, 2014.

Barnes, E. A. and Fiore, A. M.: Surface ozone variability and the jet position: Implications for projecting future air quality, Geophys. Res. Lett., 40, 2839-2844, https://doi.org/10.1002/grl.50411, 2013.

Bengtssen, J., Hodges, K. I., and Roeckner, E.: Storm tracks and climate change, J. Climate, 19, 3518-3543, 2006.

Brown-Steiner, B. and Hess, P.: Asian influence on surface ozone in the United States: a comparison of chemistry, seasonality, 
and transport mechanisms, J. Geophys. Res., 116, D17309, https://doi.org/10.1029/2011JD015846, 2011.

Butchart, N. and Scaife, A. A.: Removal of chlorofluorocarbons by increased mass exchange between the stratosphere and troposphere in a changing climate, Nature, 410, 799-802, https://doi.org/10.1038/35071047, 2001.

Christensen, J. H., Krishna Kumar, K., Aldrian, E., An, S.-I., Cavalcanti, I. F. A., de Castro, M., Dong, W., Goswami, P., Hall, A., Kanyanga, J. K., Kitoh, A., Kossin, J., Lau, N.-C., Renwick, J., Stephenson, D. B., Xie, S.-P., and Zhou, T.: Climate phenomena and their relevance for future regional climate change, in: Climate Change 2013: The Physical Science Basis, Contribution of Working Group I to the Fifth Assessment Report of the Intergovernmental Panel on Climate Change, edited by: Stocker, T. F., Qin, D., Plattner, G.-K., Tignor, M., Allen, S. K., Boschung, J., Nauels, A., Xia, Y., Bex, V., and Midgley, P. M., Cambridge University Press, Cambridge, UK and New York, NY, USA, 12171308, 2013.

Collins, M., Knutti, R., Arblaster, J., Dufresne, J.-L., Fichefet, T., Friedlingstein, P., Gao, X., Gutowski, W. J., Johns, T., Krinner, G., Shongwe, M., Tebaldi, C., Weaver, A. J., and Wehner, M.: Long-term climate change: projections, commitments and irreversibility, in: Climate Change 2013: The Physical Science Basis, Contribution of Working Group I to the Fifth Assessment Report of the Intergovernmental Panel on Climate Change, edited by: Stocker, T. F., Qin, D., Plattner, G.-K., Tignor, M., Allen, S. K., Boschung, J., Nauels, A., Xia, Y., Bex, V., and Midgley, P. M., Cambridge University Press, Cambridge, UK and New York, NY, USA, 2013.

Collins, W. J., Derwent, R. G., Johnson, C. E., and Stevenson, D. S.: A comparison of two schemes for the convective transport of chemical species in a Lagrangian global chemistry model, Q. J. Roy. Meteor. Soc., 128, 991-1009, 2002.

Cooper, O. R., Forster, C., Parrish, D., Trainer, M., Dunlea, E., Ryerson, T. B., Hübler, G., Fehsenfeld, F., Nicks, D., Holloway, J., Nowak, J. Brock, C., de Gouw, J., Warneke, C., Roberts, J., Flocke, F., and Moody, J.: A case study of trans-Pacific warm conveyor belt transport: the influence of merging airstreams on trace gas import to North America, J. Geophys. Res., 109, D23S08, https://doi.org/10.1029/2003JD003624, 2004.

Cooper, O. R., Oltmans, S. J., Johnson, B. J., Brioude, J., Angevine, W., Trainer, M., Parrish, D. D., Ryerson, T. R., Pollack, I., Cullis, P. D., Ives, M. A., Tarasick, D. W., AlSaadi, J., and Stajner, I.: Measurement of western US baseline ozone from the surface to the tropopause and assessment of downwind impact regions, J. Geophys. Res., 116, D00V03, https://doi.org/10.1029/2011JD016095, 2011.

Deser, C. A., Phillips, S., Bourdette, V., and Teng, H.: Uncertainty in climate change projections: the role of internal variability, Clim. Dynam., 38, 527-546, https://doi.org/10.1007/s00382010-0977-x, 2012.

Doherty, R. M., Stevenson, D. S., Collins, W. J., and Sanderson, M. G.: Influence of convective transport on tropospheric ozone and its precursors in a chemistry-climate model, Atmos. Chem. Phys., 5, 3205-3218, https://doi.org/10.5194/acp-5-3205-2005, 2005.

Doherty, R. M., Wild, O., Shindell, D. T., Zeng, G., MacKenzie, I. A., Collins, W. J., Fiore, A. M., Stevenson, D. S., Dentener, F. J., Schultz, M. G., Hess, P., Derwent, R. G., and Keating, T. J.:
Impacts of climate change on surface ozone and intercontinental ozone pollution: a multi-model study, J. Geophys. Res.-Atmos., 118, 3744-3763, https://doi.org/10.1002/jgrd.50266, 2013.

Fang, Y., Fiore, A. M., Horowitz, L. W., Gnanadesikan, A., Held, I., Chen, G., Vecchi, G., and Levy, H.: The impacts of changing transport and precipitation on pollutant distributions in a future climate, J. Geophys. Res., 116, D18303, https://doi.org/10.1029/2011JD015642, 2011.

Forkel, R. and Knoche, R.: Regional climate change and its impact on photooxidant concentrations in southern Germany: simulations with a coupled regional climatechemistry model, J. Geophys. Res., 111, D12302, https://doi.org/10.1029/2005JD006748, 2006.

Gregory, D. and Rowntree, P. R.: A mass flux scheme with representation of cloud ensemble characteristics and stability-dependent closure, Mon. Weather Rev., 118, 1483-1506, 1990.

Held, I. M. and Soden, B. J.: Robust response of the hydrological cycle to global warming, J. Climate, 19, 5686-5699, 2006.

Holzer, M. and Boer, G. J.: Simulated changes in atmospheric transport climate, J. Climate, 14, 4398-4420, 2001.

Kang, S. M., Deser, C., and Polvani, L. M.: Uncertainty in climate change projections of the Hadley circulation: the role of internal variability, J. Climate, 26, 7541-7554, https://doi.org/10.1175/JCLI-D-12-00788.1, 2013.

Kar, J., Bremer, H., Drummond, J. R., Rochon, Y. J., Jones, D. B. A., Nichitiu, F., Zou, J., Liu, J., Gille, C., J. C., Edwards, P., D. P., Deeter, M. N., Francis, G., Ziskin, D., and Warner, J.: Evidence of vertical transport of carbon monoxide from Measurement of Pollution in the Troposphere (MOPITT), Geophys. Res. Lett., 31, L23105, https://doi.org/10.1029/2004GL021128, 2004.

Knowland, K. E., Doherty, R. M., and Hodges, K. I.: The effects of springtime mid-latitude storms on trace gas composition determined from the MACC reanalysis, Atmos. Chem. Phys., 15, 3605-3628, https://doi.org/10.5194/acp-15-3605-2015, 2015.

Lamarque, J.-F., Shindell, D. T., Josse, B., Young, P. J., Cionni, I., Eyring, V., Bergmann, D., Cameron-Smith, P., Collins, W. J., Doherty, R., Dalsoren, S., Faluvegi, G., Folberth, G., Ghan, S. J., Horowitz, L. W., Lee, Y. H., MacKenzie, I. A., Nagashima, T., Naik, V., Plummer, D., Righi, M., Rumbold, S. T., Schulz, M., Skeie, R. B., Stevenson, D. S., Strode, S., Sudo, K., Szopa, S., Voulgarakis, A., and Zeng, G.: The Atmospheric Chemistry and Climate Model Intercomparison Project (ACCMIP): overview and description of models, simulations and climate diagnostics, Geosci. Model Dev., 6, 179-206, https://doi.org/10.5194/gmd-6179-2013, 2013.

Lang, C. and Waugh, D. W.: Impact of climate change on the frequency of Northern Hemisphere summer cyclones, J. Geophys. Res., 116, D04103, https://doi.org/10.1029/2010JD014300, 2011.

Langford, A. O., Senff, C. J., Alvarez II, R. J., Brioude, J., Cooper, O. R., Holloway, J. S., Lin, M. Y., Marchbanks, R. D., Pierce, R. B., Sandberg, S. P., Weickmann, A. M., and Williams, E. J.: An overview of the 2013 Las Vegas Ozone Study (LVOS): impact of stratospheric intrusions and long-range transport on surface air quality, Atmos. Environ., 109, 305-322, https://doi.org/10.1016/j.atmosenv.2014.08.040, 2015.

Leibensperger, E. M., Mickley, L. J., and Jacob, D. J.: Sensitivity of US air quality to mid-latitude cyclone frequency and impli- 
cations of 1980-2006 climate change, Atmos. Chem. Phys., 8, 7075-7086, https://doi.org/10.5194/acp-8-7075-2008, 2008.

Levine, X. J. and Schneider, T.: Response of the Hadley circulation to climate change in an Aquaplanet GCM to a simple representation of ocean heat transport, J. Atmos. Sci., 68, 769-783, 2011.

Lin, M., Fiore, A. M., Horowitz, L. W., Cooper, O. R., Naik, V., Holloway, J., Johnson, B. I., Middlebrook, A. N., Oltmans, S. J., Pollack, I. B., Ryerson, T. B., Warner, J. X., Wiedinmyer, C., Wilson, J., and Wynam, B.: Transport of Asian ozone pollution into surface air over the western United States in spring, J. Geophys. Res., 117, D00V07, https://doi.org/10.1029/2011JD016961, 2012.

Lin, M., Horowitz, L. W., Oltmans, S. J., Fiore, A. M., and Fan, S.: Tropospheric ozone trends at Manna Loa observatory tied to decadal climate variability, Nat. Geosci., 7, 136-143, https://doi.org/10.1038/NGEO2066, 2014.

Lin, M., Fiore, A. M., Horowitz, L. W., Langford, A. O., Oltmans, S. J., Tarasick, D., and Reider, H. E.: Climate variability modulates western US ozone air quality in spring via deep stratospheric intrusions, Nat. Commun., 6, 7105, https://doi.org/10.1038/ncomms8105, 2015.

Lorenz, D. J. and DeWeaver, E. T.: Tropopause height and zonal wind response to global warming in the IPCC scenario integrations, J. Geophys. Res., 112, D10119, https://doi.org/10.1029/2006JD008087, 2007.

Lu, J., Vecchi, G. A., and Reichler, T., T.: Expansion of the Hadley cell under global warming, Geophys. Res. Lett., 34, L06805, https://doi.org/10.1029/2006GL028443, 2007.

Ma, J., Xie, S.-P., and Kosaka, Y., Y.: Mechanisms for tropical tropospheric circulation change in response to global warming, J. Climate, 25, 2979-2994, 2012.

Manabe, S. and Wetherald, R. T.: Effects of doubling $\mathrm{CO}_{2}$ concentration on the climate of a general circulation model, J. Atmos. Sci., 32, 3-15, 1975.

Masato, G., Hoskins, B. J., and Woollings, T. J.: Winter and summer Northern Hemisphere blocking in CMIP5 models, J. Climate, 26, 7044-7059, https://doi.org/10.1175/JCLI-D-12-00466.1, 2013.

Mickley, L. J., Jacob, D. J., and Field, B. D.: Effects of future climate change on regional air pollution episodes in the United States, Geophys. Res. Lett., 31, L24103, https://doi.org/10.1029/2004GL021216, 2004.

Monks, S. A., Arnold, S. R., Emmons, L. K., Law, K. S., Turquety, S., Duncan, B. N., Flemming, J., Huijnen, V., Tilmes, S., Langner, J., Mao, J., Long, Y., Thomas, J. L., Steenrod, S. D., Raut, J. C., Wilson, C., Chipperfield, M. P., Diskin, G. S., Weinheimer, A., Schlager, H., and Ancellet, G.: Multi-model study of chemical and physical controls on transport of anthropogenic and biomass burning pollution to the Arctic, Atmos. Chem. Phys., 15, 3575-3603, https://doi.org/10.5194/acp-15-3575-2015, 2015.

Murazaki, K. and Hess. P.: How does climate change contribute to surface ozone change over the United States?, J. Geophys. Res., 111, D05301, https://doi.org/10.1029/2005JD005873, 2006.

Neu, J. L., Flury, T., Manney, G. L., Santee, M. L., Livesey, N. J., and Worden, J.: Tropospheric ozone variations governed by changes in stratospheric circulation, Nat. Geosci., 7, 340-344, https://doi.org/10.1038/ngeo2138, 2014.

Orbe, C., Holzer, M., Polvani, L. M., and Waugh, D.: Air-mass origin as a diagnostic of tropospheric transport, J. Geophys. Res.Atmos., 118, 1459-1470, 2013a.
Orbe, C., Holzer, M., Polvani, L. M., and Waugh, D.: Air-mass origin as a diagnostic of tropospheric transport, J. Geophys. Res. Atmos., 118, 1459-1470, https://doi.org/10.1002/jgrd.50133, $2013 b$.

Orbe, C., Newman, P. A., Waugh, D. A., Holzer, M., Oman, L., Polvani, L. M., and Li, F.: Air-mass origin in the Arctic, Part II: Response to increases in greenhouse gases, J. Climate, 28, 91059120, 2015.

Prather, M. J., Zhu, X., Tang, Q., Hsu, J., and Neu, J. L.: An atmospheric chemist in search of the tropopause, J. Geophys. Res.-Atmos., 116, 1-10, https://doi.org/10.1029/2010JD014939, 2011.

Pickering, K. E., Thompson, A. M., Wang, Y., Tao, W.-K., McNamara, D. P., Kirchhoff, V. W. J. H., Heikes, B. G., Sachse, G. W., Bradshaw, J. D., Gregory, G. L, and Blake, D. R.: Convective transport of biomass burning emissions over Brazil during TRACE A, J. Geophys. Res., 101, 23993-24012, 1996.

Racherla, P. N. and Adams, P. J.: The response of surface ozone to climate change over the Eastern United States, Atmos. Chem. Phys., 8, 871-885, https://doi.org/10.5194/acp-8-8712008, 2008.

Reichler, T., Dameris, M., and Sausen. R.: Determining the tropopause height from gridded data, Geophys. Res. Lett., 30, 2042, https://doi.org/10.1029/2003GL018240, 2003.

Santer, B. D., Sausen, R., Wigley, T. M. L., Boyle, J. S., AchutaRao, K., Doutriaux, C., Hansen, J. E., Meehl, G. A., Roeckner, E., Ruedy, R., Schmidt, G., and Taylor, K. E.: Behavior of tropopause height and atmospheric temperature in models, reanalyses, and observations: decadal changes, J. Geophys. Res., 108, 4002, https://doi.org/10.1029/2002JD002258, 2003.

Schultz, M. and Rast, S.: RETRO report on emission data sets and methodologies for estimating emissions, work package 1, deliverable D1-6, EU-Contract EVK2-CT-2002-00170, Max Planck Inst. For Meteorol., Hamburg, Germany, available at: http://retro-archive.iek.fz-juelich.de/data/documents/reports/ RETRO_Final_Report.pdf (last access: 27 November 2017), 2007.

Scinocca, J. F. and McFarlane, N. A.: The variability of modelled tropical precipitation, J. Atmos. Sci., 61, 1993-2015, 2004.

Seo, K.-H., Frierson, D. M. W., and Son, J.-H.: A mechanism for future changes in Hadley circulation strength in CMIP5 climate change simulations, Geophys. Res. Lett., 40, 5251-5258, https://doi.org/10.1002/2014GL060868, 2014.

Shaw, T. A., Baldwin, M., Barnes, E. A., Caballero, R., Garfinkel, C. I., Hwang, Y.-T., Li, C., O’Gorman, P. A., Rivière, G., Simpson, I. R., and Voigt, A.: Storm track processes and the opposing influences of climate change, Nat. Geosci., 9, 656-664, https://doi.org/10.1038/ngeo2783, 2016.

Shepherd, T. G.: Atmospheric circulation as a source of uncertainty in climate change projections, Nat. Geosci., 7, 703-708, 2014.

Shindell, D. T., Faluvegi, G., Stevenson, D. S., Krol, M. C., Emmons, L. K., Lamarque, J.-F., Petron, G., Dentener, F. J., Ellingsen, K., Schultz, M. G., Wild, O., Amann, M., Atherton, C. S., Bergmann, D. J., Bey, I., Butler, T., Cofala, J., Collins, W. J., Derwent, R. G., Doherty, R. M., Drevet, J., Eskes, H. J., Fiore, A. M., Gauss, M., Hauglustaine, D. A., Horowitz, L. W., Isaksen, I. S. A., Lawrence, M. G., Montanaro, V., Müller, J.-F., Pitari, G., Prather, M. J., Pyle, J. A., Rast, S., Rodriguez, J. M., Sanderson, M. G., Sav- 
age, N. H., Strahan, S. E., Sudo, K., Szopa, S., Unger, N., van Noije, T. P. C., and Zeng, G.: Multimodel simulations of carbon monoxide: comparison with observations and projected near-future changes, J. Geophys. Res., 111, D19306, https://doi.org/10.1029/2006JD007100, 2006.

Shindell, D. T., Chin, M., Dentener, F., Doherty, R. M., Faluvegi, G., Fiore, A. M., Hess, P., Koch, D. M., MacKenzie, I. A., Sanderson, M. G., Schultz, M. G., Schulz, M., Stevenson, D. S., Teich, H., Textor, C., Wild, O., Bergmann, D. J., Bey, I., Bian, H., Cuvelier, C., Duncan, B. N., Folberth, G., Horowitz, L. W., Jonson, J., Kaminski, J. W., Marmer, E., Park, R., Pringle, K. J., Schroeder, S., Szopa, S., Takemura, T., Zeng, G., Keating, T. J., and Zuber, A.: A multi-model assessment of pollution transport to the Arctic, Atmos. Chem. Phys., 8, 5353-5372, https://doi.org/10.5194/acp-8-5353-2008, 2008.

Simpson, I. R., Shaw, T. A., and Seager. R.: A diagnosis of the seasonally and longitudinally varying midlatitude circulation response to global warming, J. Atmos. Sci., 71.7, 2489-2515, 2014.

Task Force on Hemispheric Transport of Air Pollution (TFHTAP): Hemispheric Transport of Air Pollution 2010, Air Pollut. Stud. 17, edited by: Dentener, F., Keating, T., and Akimoto, H., UNECE, Geneva, Switzerland, available at: http://www.htap.org/ (last access: 1 January 2017), 2010.

Ulbrich, U., Leckebusch, G. C., and Pinto, J. G.: Extra-tropical cyclones in the present and future climate: a review, Theor. Appl. Climatol., 96, 117-131, 2009.

Vallis, G. K., Zurita-Gotor, P., Cairns, C., and Kidston, J.: Response of the large-scale structure of the atmosphere to global warming, Q. J. Roy. Meteor. Soc., 141, 1479-1501, https://doi.org/10.1002/qj.2456, 2015.

van der Werf, G. R., Randerson, J. T., Giglio, L., Collatz, G. J., Kasibhatla, P. S., and Arellano Jr., A. F.: Interannual variability in global biomass burning emissions from 1997 to 2004, Atmos. Chem. Phys., 6, 3423-3441, https://doi.org/10.5194/acp-6-34232006, 2006.

Vecchi, G. A. and Soden, B. J.: Global warming and the weakening of the tropical circulation, J. Climate, 20, 4316-4340, https://doi.org/10.1175/JCLI4258.1, 2007.
Williamson, D. L., Blackburn, M., Nakajima, K., Ohfuchi, W., Takahashi, Y. O., Hayashi, Y.-Y., Nakamura, H., Ishiwatari, M., Mcgregor, J. L., Borth, H., Wirth, V., Frank, H., Bechtold, P., Wedi, N. P., Tomita, H., Satoh, M., Zhao, M., Held, I. M., Suarez, M. J., Lee, M.-I., Watanabe, M., Kimoto, M., Liu, Y., Wang, Z., Molod, A., Rajendran, K., Kitoh, A., and Stratton, R.: The AquaPlanet Experiment (APE): response to changed meridional SST profile, J. Meteorol. Soc. Jpn., 91A, 57-89, 2013.

Wu, S., Mickley, L. J., Leibensperger, E. M., Jacob, D. J., Rind, D., and Streets, D. G.: Effects of 2000-2050 global change on ozone air quality in the United States, J. Geophys. Res., 113, D06302, https://doi.org/10.1029/2007JD008917, 2008.

Wu, Y., Ting, M., M., Seager, R., Cane, M. A., and Huang, H.-P.: Changes in storm tracks and energy transports in a warmer climate simulated by the GFDL CM2.1 Model, Clim. Dynam., 37, 53-72, 2011.

Yin, J. H.: A consistent poleward shift of the storm tracks in simulations of 21st century climate, Geophys. Res. Lett., 32, L18701, https://doi.org/10.1029/2005GL023684, 2005.

Young, P. J., Archibald, A. T., Bowman, K. W., Lamarque, J.-F., Naik, V., Stevenson, D. S., Tilmes, S., Voulgarakis, A., Wild, O., Bergmann, D., Cameron-Smith, P., Cionni, I., Collins, W. J., Dalsøren, S. B., Doherty, R. M., Eyring, V., Faluvegi, G., Horowitz, L. W., Josse, B., Lee, Y. H., MacKenzie, I. A., Nagashima, T., Plummer, D. A., Righi, M., Rumbold, S. T., Skeie, R. B., Shindell, D. T., Strode, S. A., Sudo, K., Szopa, S., and Zeng, G.: Preindustrial to end 21st century projections of tropospheric ozone from the Atmospheric Chemistry and Climate Model Intercomparison Project (ACCMIP), Atmos. Chem. Phys., 13, 20632090, https://doi.org/10.5194/acp-13-2063-2013, 2013.

Zhang, G. J. and McFarlane, N. A.: Sensitivity of climate simulations to the parameterization of cumulus convection in the Canadian Climate Center general circulation model, Atmos. Ocean, 33, 407-446, 1995. 